\title{
The curious case of eastern oyster Crassostrea virginica stock status in Apalachicola Bay, Florida
}

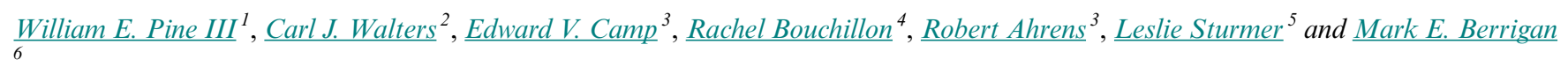

\begin{abstract}
The Apalachicola Bay, Florida, eastern oyster (Crassostrea virginica) industry has annually produced about $10 \%$ of the U.S. oyster harvest. Today's simple individual-operator, hand-tonging, small-vessel fishery is remarkably similar to the one that began in the 1800s. Unprecedented attention is currently being given to the status of oyster resources in Apalachicola Bay because this fishery has become central to the decision making related to multistate water disputes in the southeastern United States, as well as millions of dollars in funding for restoration programs related to the Deepwater Horizon oil spill. The oyster fishery collapsed in 2012, leading to large economic losses and community concerns over the current and future status of oyster resources, ecosystem health, and local economic opportunities. We used best available data to assess what mechanism(s) may have led to the collapse of the Apalachicola Bay oyster fishery. We then assessed the efficacy of alternative management strategies (e.g., restoration, fishery closure) to accelerate oyster population recovery. Our results suggest that the Apalachicola Bay oyster population is not overfished in the sense that recruitment has been limited by harvest, but that the 2012 collapse was driven by lower-than-average numbers and/or poor survival of juvenile oysters in the years preceding the collapse. This reduction in recruitment not only reduced the biomass of oysters available to harvest, but from a population resilience perspective, likely reduced the amount of dead shell material available as larval settlement area. Although the Apalachicola Bay oyster fishery has proven resilient over its $>150$-year history to periods of instability, this fishery now seems to be at a crossroads in terms of continued existence and possibly risks an irreversible collapse. How to use the restoration funds available, and which restoration and management practices to follow, are choices that will determine the long-term viability of the Apalachicola Bay oyster fishery.
\end{abstract}

Key Words: adaptive management; Apalachicola; harvest management;oysters; restoration

\section{INTRODUCTION}

Eastern oyster (Crassostrea virginica) populations are significant components of coastal ecosystems, playing numerous important ecological, cultural, and economic roles. Eastern oyster (hereafter, "oyster") populations often create complex reefs of living oysters of multiple size and age classes living on and among dead oyster shell material known as cultch (Fig. 1). These oyster reefs create key habitat for numerous fish, invertebrate, and bird species, many of which have large recreational and commercial value (e.g., red drum [Sciaenops ocellatus], Florida stone crab [Menippe mercenaria]) or are species of special concern (e.g., American Oystercatcher [Haematopus palliatus]). Oyster reefs also function as barrier islands in many areas, dampening wave action to reduce coastal erosion and protect human coastal communities from storm damage (Borsje et al. 2011), as well as improve coastal water quality (Coen et al. 2007). Globally oyster reef distribution has declined by as much as $85 \%$ for a variety of reasons including overharvest, disease, and poor water quality (Beck et al. 2011). Well-known U.S. oyster fisheries such as those in the Chesapeake Bay are much smaller than historic levels (Wilberg et al. 2011). The largest wild oyster fishery in the world currently is in the Gulf of Mexico, which supplies about $50 \%$ of the U.S. commercial oyster harvests (Beck et al. 2011).

Florida provides about $10 \%$ of the U.S. commercial harvest (MacKenzie 1996), with the majority of oyster landings coming from Apalachicola Bay (Dugas et al. 1997). Apalachicola Bay oysters have traditionally been viewed as a high-quality seafood product, and Apalachicola oysters are marketed by name for their size and flavor qualities. Oyster fisheries and oyster processing are a significant component of the local economy, supporting more than 1000 jobs and about half of the revenues for some coastal counties (Whitfield and Beaumariage 1977, Havens et al. 2013).

Apalachicola Bay oyster populations have a long research and management history (Fig. 2). In a report of the U.S. Commission of Fishes and Fisheries, as part of a survey of oyster regions of Apalachicola Bay, Florida, Swift (1897) said:

The oysters of this bed, especially those found near the 3-foot curve off Cat Point, are of the very finest quality, and it is probable that no better flavored oysters can be found in any part of the country. They are not only exceptionally good in flavor, but are large and fat. Swift (1897:210)

This bed [South Lump], like the others surrounding it on the north side, was formerly very productive, but it, like the others, was so overworked that it became depleted a few years ago. Since that time, these beds have been left to recuperate, and it seems probable that, if left undisturbed, they will soon recover their former productiveness. Swift (1897:203)

${ }^{1}$ Department of Wildlife Ecology and Conservation, University of Florida, ${ }^{2}$ University of British Columbia, ${ }^{3}$ Fisheries and Aquatic Sciences Program, School of Forest Resources and Conservation, University of Florida, ${ }^{4}$ School of Natural Resources and the Environment, University of Florida, ${ }^{5}$ Shellfish Aquaculture Extension Program, School of Forest Resources and Conservation, University of Florida, ${ }^{6}$ Applied Aquaculture LLC 
Fig. 1. Generalized eastern oyster (Crassostrea virginica) lifecycle and equations used in the stock assessment model (Table A2.1 in Appendix 2) developed to assess status and trends in the Apalachicola oyster population.

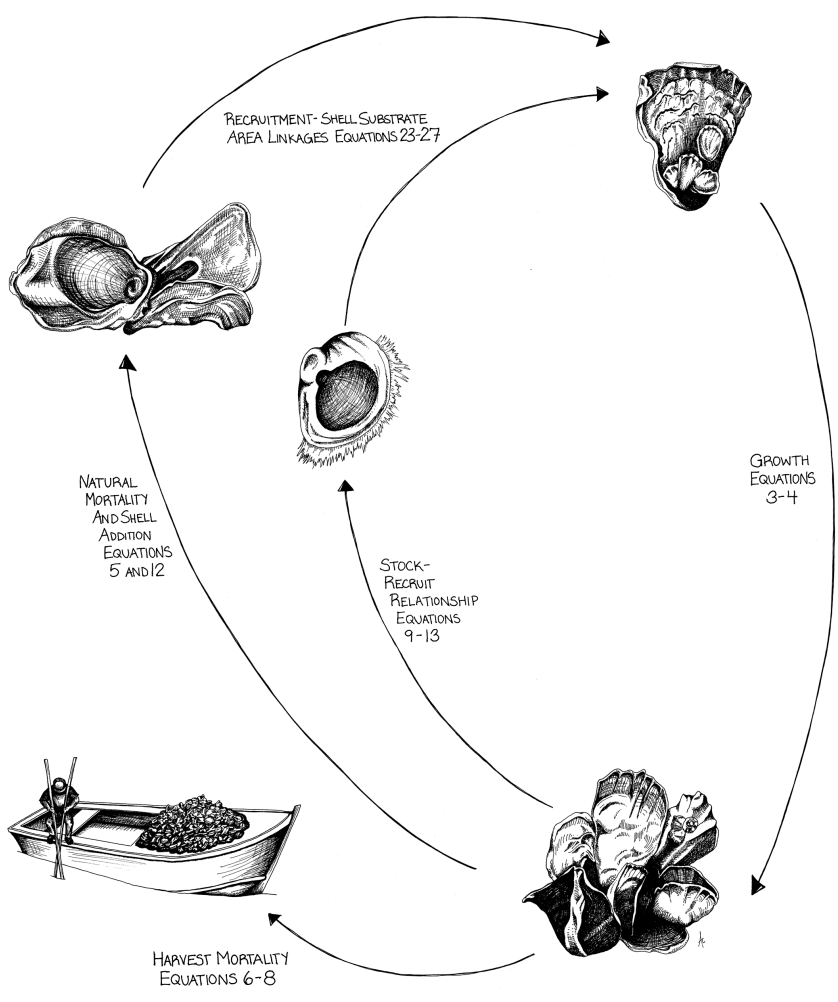

This is the first of several large declines in Apalachicola oyster populations reported since the late nineteenth century. The most recent occurred in 2012, when Apalachicola Bay experienced large declines in the abundance of harvestable oysters, leading the State of Florida to request a Federal Fisheries Disaster declaration from the National Marine Fisheries Service. This decline resulted in large economic losses in the region, leading to a 2012 community-based review of environmental conditions in Apalachicola Bay (Havens et al. 2013, Camp et al. 2015). This review followed decades of earlier agency and academic research on Apalachicola Bay ecology in the 1970s-2000s (Livingston 1991, 2002, 2015).

Despite the economic importance of the Apalachicola oyster fishery and expanded attention to the ecosystem services provided by oyster populations across their distribution (Coen et al. 2007, Beck et al. 2011, Seavey et al. 2011), the status of oyster populations in quantitative terms, i.e., terms useful for making management and restoration decisions, is not well known in many areas (Wilberg et al. 2011). To inform Apalachicola oyster fishery management and restoration, it is specifically critical to understand (1) the role that fishing effort has played in the current oyster fishery collapse to determine best fishing practices in the future and (2) what specific strategies or scenarios (e.g., shelling of oyster bars, restrictive harvest policies) will lead to the most rapid or most certain recovery of the fishery.

We analyzed available data in a population dynamics model to assess what mechanism(s) likely led to the collapse of the Apalachicola Bay oyster fishery. An original contribution is that our model captures the feedback between natural mortality and the accretion of shell material as substrate for oyster larvae (spat) settlement and growth, and the linkages between harvest (which removes both oyster shell material and live oysters) and recruitment. We then assessed the efficacy of alternative management strategies (e.g., habitat restoration, fishery closures) and scenarios (area for and frequency of adding shell material) to accelerate oyster population and fishery recovery to help inform planning efforts for community-led restoration programs designed to promote resilience in this resource-dependent community (Camp et al. 2015).

Note that we did not study or reach any conclusions about any effect of water withdrawals affecting the Apalachicola River Basin or oyster populations in Apalachicola Bay. This is an area that warrants future research.

\section{STUDY SITE}

Apalachicola Bay is a shallow estuary (mean depth $<3 \mathrm{~m}$ ) of approximately 63,000 ha enclosed by a series of barrier islands with an east-west orientation. Geologic surveys of the bay suggest that the primary oyster bars are perpendicular to the orientation of the bay along ancient sandy deltas, and these bars became expansive 1200-2400 years ago (Twichell et al. 2010). The primary source of freshwater input into Apalachicola Bay is the Apalachicola River, and river discharge has a strong influence on the salinity, nutrient dynamics, and other aspects of the Apalachicola Bay ecosystem (Livingston et al. 1997).

\section{Fishery overview}

The commercial oyster fishery in Apalachicola was first described in the 1880s, and extensive surveys in the 1890s reported established fisheries with commercial canning operations, as well as documentation of oyster bars being "overworked" and no longer producing a commercial harvest (Swift 1897, Dugas et al. 1997; Fig. 2). Oyster landings from Apalachicola Bay in the last half century average between 91,000 and $272,000 \mathrm{~kg}$ of meat, or about $90 \%$ of Florida's commercial oyster harvest (Dugas et al. 1997; Fig. 3), with the majority of harvest coming from public reefs where oysters are harvested via hand tonging (Whitfield and Beaumariage 1977). As early as 1881, it was recognized by Florida statute that the recycling or placing of oyster shell on oyster reefs to provide substrate for oyster spat (known as "shelling") was important to promote sustainable oyster harvest (Whitfield and Beaumariage 1977). In 1949, a management program was established to replace oyster shell on public reefs, and the amount of material has varied annually depending on funding and availability of material (Whitfield and Beaumariage 1977).

In 1985, Hurricane Elena caused significant damage to oyster resources in Apalachicola Bay, leading to highly restrictive regulations, on-water harvest check stations, and intensive shelling operations on a subset of reefs (Berrigan 1990). Beginning in 1986, a revised landings and effort reporting system was required for all commercially harvested marine species, in contrast to the prior voluntary reporting program in place. Based on data 
Fig. 2. Time line of key events and management actions in the Apalachicola Bay, Florida oyster fishery, 1836-2013.

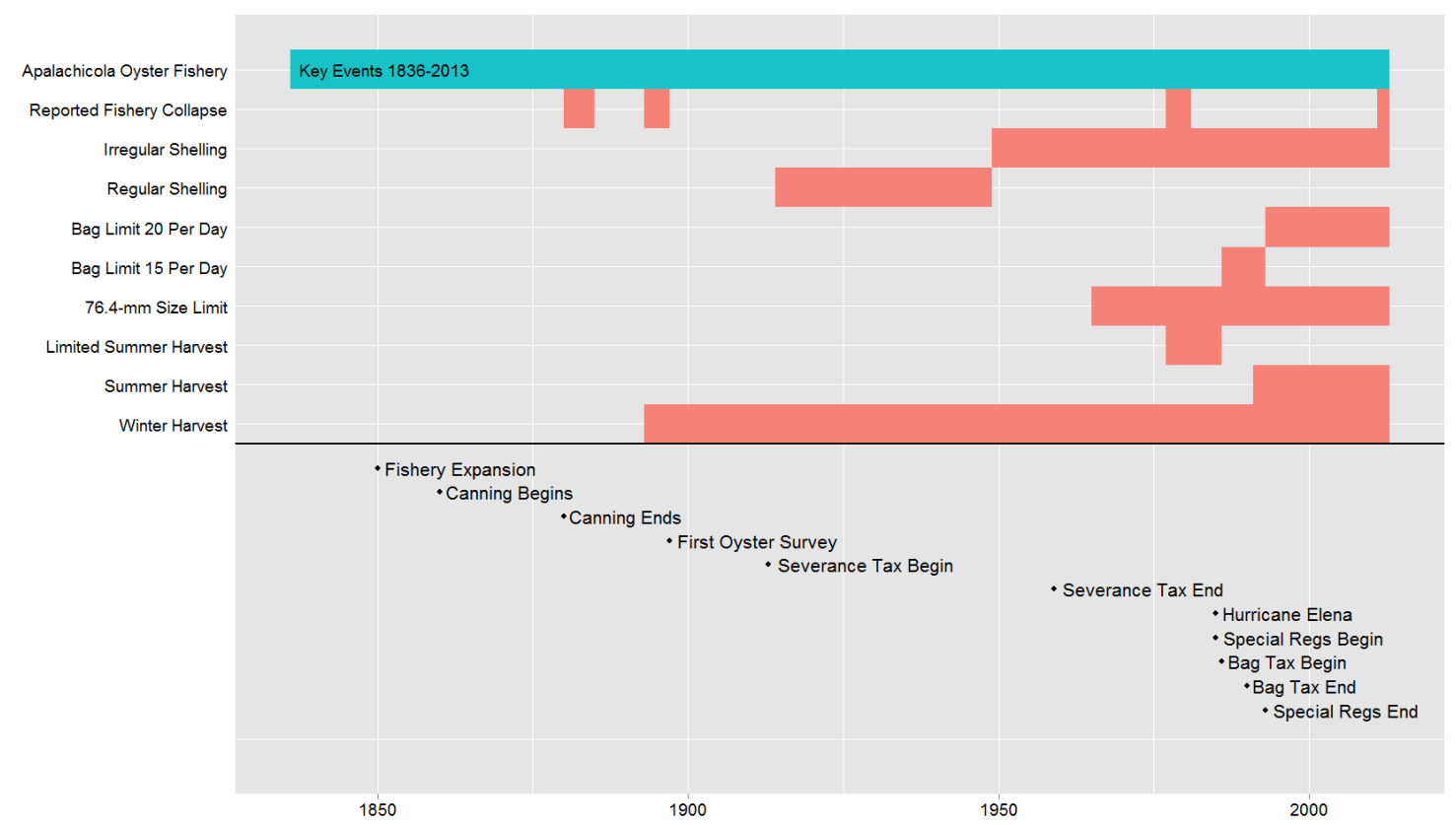

since 1986, the number of Apalachicola Bay oyster harvesters declined from about 1000 in the late 1980 s to around 400-600 throughout most of the 1990s and early 2000s, before increasing since 2008 to about 1000 license holders at present (Fig. 3a). The number of oyster fishing trips follows a similar pattern, with about 30,000 trips reported in 1988 , declining to about 10,000 trips in the mid-1990s, and then varying between 10,000 and 25,000 trips until 2006, when the number of trips increased to about 40,000 annually in recent years. Large declines in landings were reported beginning in the fall of 2012, and landings and trips declined dramatically in 2013 (Camp et al. 2015). Oyster regulations in Apalachicola Bay are currently managed using a system of seasons, spatial closures, bag limits, and size limits, but on-water check stations and a bag tax to fund research and monitoring programs were ended in the early 1990s (Fig. 2).

\section{METHODS}

\section{Oyster stock assessment model}

We developed an age-structured oyster stock assessment model that reconstructs historical abundance patterns and allows for exploration of future alternative management options. The model represents a single oyster population in some area of interest; that region may be some large management area like Apalachicola Bay or some much smaller habitat type or site within a larger region. The model is implemented in an Excel spreadsheet to allow portability and ease of examination of model structure and calculations; an example copy of this spreadsheet is available as a supplemental file (see Appendix 1).

Model population dynamics calculations (growth, survival, recruitment) are made at a monthly time resolution to account for the rapid growth and mortality of oysters, to assist in
Fig. 3. Reported Apalachicola Bay, Florida oyster fishing license holders (a), annual oyster fishing trips (b), average catch per trip from 1986-2012 (c), reported oyster fishery landings (d), and amount of cultch (shell) material planted in Apalachicola Bay as a restoration tool from 1880-2012 (e). Prior to 1986 , landings data were reported under a voluntary reporting system (red verticle line in panel d). From 1986 to the present, landings and effort were tracked via the Florida Fish and Wildlife Conservation Commission Trip Ticket Program.
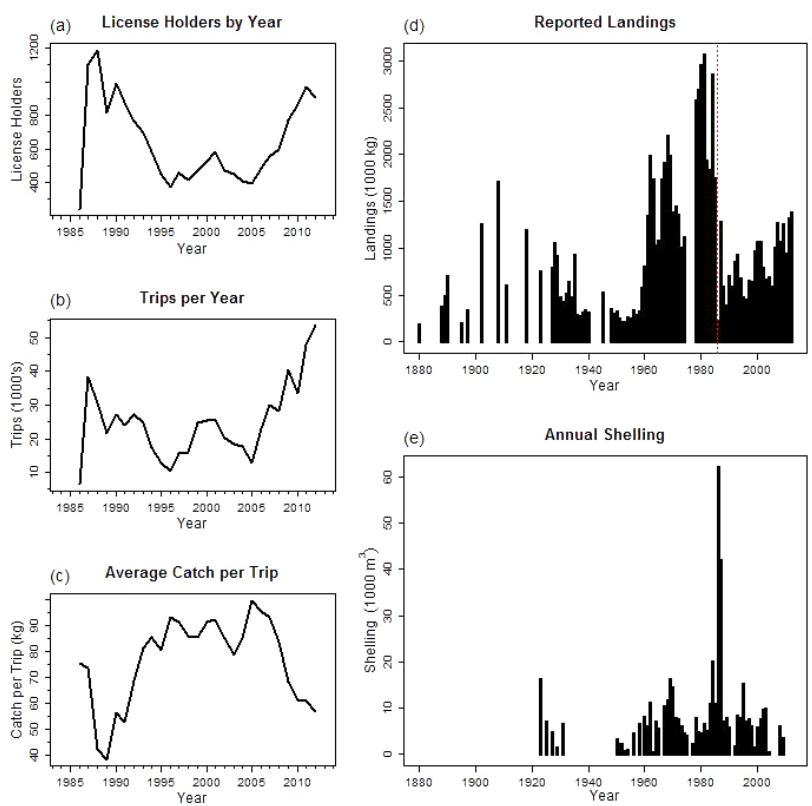
interpretation of seasonal harvesting data, and for evaluation of seasonal harvesting policies, e.g., seasonal closures. Three timeaccounting variables are used in the model equations: $y$ for calendar year $\left(\mathrm{y}=1, \ldots, \mathrm{n}_{\mathrm{y}}\right), m$ for month of year $(\mathrm{m}=1, \ldots, 12)$, and $t$ for month from start of a time simulation $\left(\mathrm{t}=1, \ldots, 12 \mathrm{n}_{\mathrm{y}}\right)$. The model predicts matrices of oyster numbers $\mathrm{N}_{\mathrm{a}, \mathrm{t}}$ and shell lengths $\mathrm{L}_{\mathrm{a}, \mathrm{t}}$ by month of age. Using monthly fishing efforts $\mathrm{E}_{\mathrm{y}}$ $\mathrm{m}$, the model predicts monthly catches $\mathrm{C}_{\mathrm{y}, \mathrm{m}}$ for statistical comparison to historic data, while allowing for interannual variations in recruitment, growth, and survival (equation 1 in Table A2.1, Appendix 2). For our Apalachicola Bay case history, observed fishery landings and effort data by month were compiled for 1986-2013 from information provided by the Florida Fish and Wildlife Conservation Commission. We developed a standardized index of oyster recruitment using fisheries-independent survey data of oysters by 5-mm size classes collected by the Florida Department of Agriculture and Consumer Services (DACS) on the major commercial fishing reefs in Apalachicola Bay (available from 1990 through 2013). Full details on our population dynamics model and its application to the Apalachicola Bay case study are available in Appendix 2.

\section{Simulation of management actions}

When tuned to the uncertainty in oyster population dynamics in Apalachicola Bay, this model can be used to evaluate future fishery outcomes of alternative management actions. As an example, how harvest or environmental perturbations affect persistence of shell material essential for successful recruitment represents a key uncertainty in managing oyster populations. If shell material is removed from the oyster bars as fishermen cull legal oysters from sublegal sizes and associated shell material, and these sublegal oysters and shell are discarded away from the oyster bar, then this loss rate (discard mortality of both live sublegal oysters and shell material) could be substantial. Such evaluations are a critical part of any adaptive management program designed to learn more about the system (Camp et al. 2015).

We used the model to assess the effect on future oyster fishery landings of a variety of potential management actions under different assumptions about oyster recruitment patterns and processes. We first assumed future average oyster recruitment levels similar to those observed in 2004-2013 and explored four management action scenarios: (1) no management action taken; (2) no management action taken, but assuming a different function form of the recruitment relationship (i.e., assuming a Beverton-Holt recruitment function rather than a Ricker recruitment function); (3) initiating a substantial shell addition program involving restoration of about 50 ha (a little more than the historic average annual shelling) for each of four years (2014-2018); and (4) reducing fishing effort by half (from around 4000 trips/month to 2000) over the next six years (2014-2020). We then evaluated actions 1,3 , and 4 under the alternative assumption that future average oyster recruitment remains low (similar to 2011-2012 levels). Finally, we assessed how a future $20 \%$ annual loss rate of shell material would impact oyster population recovery under no action (scenario 1) and reshelling (scenario 3).

\section{RESULTS}

\section{Oyster stock assessment model}

The oyster stock assessment model (Appendix 2) appears to represent well the oyster population dynamics in Apalachicola Bay and results in a remarkably good statistical explanation of historical catches and major trends in fisheries-independent survey data. Our assessment results suggest that the Apalachicola Bay oyster population is probably not recruitment overfished; $i$. e., the observed low recruitments are not anticipated to be strictly because of overharvest of adults. Rather, the 2012 collapse instead was likely driven by lower-than-average abundance or survival of sublegal (juvenile) oysters in the years preceding the collapse. This reduction in recruitment not only reduced the biomass of oysters available to harvest, but from a population resilience perspective, likely reduced the amount of dead shell material available as area for larval settlement.

An important and surprising result of our work was the low estimate of the area of oyster bar needed to produce the estimated abundance of legal-size oysters, in other words, to support the observed harvests $\left(\mathrm{A}_{\text {total }}\right.$, about $\left.500 \mathrm{ha}\right)$. The low $\mathrm{A}_{\text {total }}$ estimates would imply very high monthly exploitation rates $\left(U_{t}\right)$, in the range of $0.1-0.15$ for recent years. This is much higher than $U_{t}$ estimated from about $1995-2010$ of around 0.05 per month, but similar to the estimates from about 1988-1990 (Fig. 4). This low estimate of $A_{\text {total }}$ has multiple potential interpretations: (1) the Apalachicola Bay fishery is being supported by recruits from a very small but productive proportion of the total oyster bar area (total area of oyster habitat including subtidal areas estimated to be about 4800 ha); (2) fishery catches have been grossly underreported; (3) DACS harvest data are not representative of average oyster densities; (4) the impact of a unit of fishing effort (fishery catchability, $q$, and hence $U_{t}$ ) has been greatly overestimated; (5) the total oyster bar area has been overestimated based on existing geological (bottom type) and other survey information; and/or (6) the model allows upward bias in exploitation rate estimates by not properly accounting for erosion of size structure at age (selective removal of faster growing individuals).

Fig. 4. Estimated monthly exploitation rate for legal ( $>76.2$ $\mathrm{mm}$ ) oysters in Apalachicola Bay, Florida.

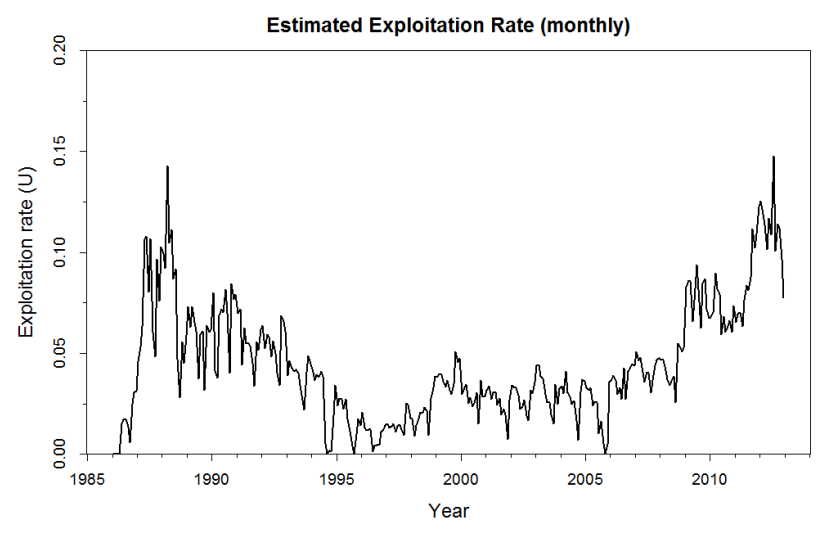


The basic problem is most likely that the model predictions of sublegal and legal abundances, i.e., size distribution, are not in fact reasonable for such high exploitation rates (interpretation 6). If exploitation rates were in reality as high as predicted, most legal oysters would be removed within a few months of reaching the 76.2-mm legal length, and the size distribution would thus be far more severely truncated than observed; i.e., the legal/sublegal density ratio would be much lower. Instead, the model "allows" very high exploitation rates without erosion in the predicted size structure because it assumes regeneration of the length distributions of sizes each month. The only way to avoid this faulty regeneration assumption would be to use a much more complex model structure involving growth-type groups. However, when we developed growth-type-group models based on five-year periods of time (Appendix 2), these models resulted in similar estimates of $\mathrm{A}_{\text {total }}$ of around 500 ha, prohibiting a conclusive dismissal of the small $\mathrm{A}_{\text {total }}$ estimate as an artifact of the model structure.

The lack of clarity regarding the area of oyster production, $\mathrm{A}_{\text {total }}$, reverberates throughout the model results. If $\mathrm{A}_{\text {total }}$ is larger than estimated, as implied by the above information, our assessment suggests a large, relatively unproductive oyster population scarcely affected by fishing harvest. Alternatively, if $\mathrm{A}_{\text {total }}$ is truly small, our assessment would suggest a highly productive population that has been relatively heavily impacted by recent fishing harvest. Therefore, although our best assessments of the available data suggest that the collapse of the Apalachicola Bay oyster fishery was not strictly due to overfishing, the model was unfortunately unable to clearly resolve the historical role that harvest has played or the relative productivity of the oyster population in Apalachicola Bay.

\section{Simulation of management actions}

The model predicted that under average "normal" recruitment and mortality rates observed from 2004-2013, oyster populations would recover in 5-10 years, even with no management action (blue lines, Fig. 5a). If recruitment remains equal to the 2004-2013 average, then adding shelling of 50 ha per year for the next 4 years was predicted to increase oyster yields to 2008-2010 levels in about 5 years, even if fishery effort remains high (green lines, Fig. 5a). Interestingly, shelling only provided a small reduction in recovery time compared with the "no action" scenario. With the same assumption of recruitment equal to the 2008-2012 average, reducing effort by half over the next 6 years (2014-2020) would result in increasing yields within 5 years, but such a reduction in effort would obviously reduce overall yield (red lines, Fig. 5a) and likely have deleterious economic effects on the community. The effects of closures or shelling additions were small relative to the effect of assuming a different functional form for the stock recruitment relationship (gray lines, Fig. 5a).

When we ran the model under the assumption that the low oyster recruitment observed in Apalachicola Bay during 2012-2013 would continue into the future, it predicted that oyster fishery recovery was less likely to occur in the absence of management actions (blue lines, Fig. 5b). If recruitment remains at 2012-2013 levels, our model predicted that even with shelling 50 ha per year for four years, the oyster population would continue to decline in 2014-2020 (red lines, Fig. 5b). Even with very high shelling rates (162 ha per year), the low-recruitment oyster population was predicted to increase only slightly (green lines, Fig. 5b) and only
Fig. 5. Observed (black circles) and model predicted (overlapping lines) oyster yields in Apalachicola Bay, Florida from 1986-2013. In panel a, 2013-2020 yield is predicted under three different scenarios based on 2004-2013 average annual recruitment rates. Scenario 1 (blue line, no closure) is a baseline prediction of oyster population yield allowing for average recruitment and based on survival rates and similar effort levels observed in 2004-2008. Scenario 1 also includes results from a "no closure" option assuming the alternative Beverton-Holt stock-recruitment function. Scenario 2 (red line, reduced effort) is similar to scenario 1 , but also reduces fishing effort by 50\% from 2013-2020. Scenario 3 (green line) assumes a shelling restoration program at a level of 50 ha per year from 2013-2017. Panel b assumes that recruitment from 2014-2020 is lower than the 2004-2013 average and similar to average recruitment estimated during 2012-2013. Three lowrecruitment scenarios are evaluated: a "no action" scenario (blue line), a low shelling area option of 50 ha for 4 years (red line), and a high shelling area option of 162 ha for 4 years (green line). Panel $\mathrm{c}$ is similar to panel a with the same scenario 1 (blue line, no closure) and a scenario 2 that assesses yield recovery under a situation where shell is removed at a rate of $20 \%$ a year from storms or fishery practices.
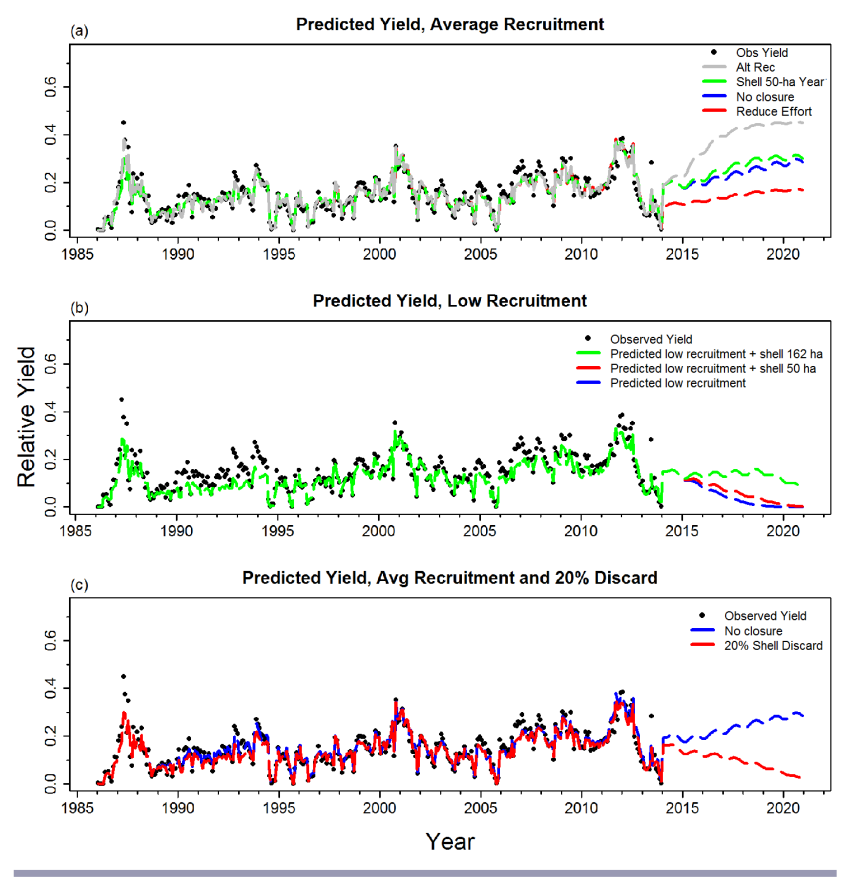

during the four years when shell additions take place (green lines, Fig. 5b).

A central finding is the importance of the protection of shell habitat and the maintenance of a "positive" shell budget. We found that the oyster fishery is unlikely to recover if shell loss, e.g., from storms, culling practices, or ocean acidification, is higher than shell deposition from natural or restoration actions (i.e., if the shell budget is negative). At a $20 \%$ annual shell loss rate, our model estimated relatively rapid oyster fishery collapse (red lines, Fig. 5c) compared with the recovery predicted even without management actions (blue lines, Fig. 5c) if no shell loss is assumed. 
Overall, the key result from our simulations was identifying the pivotal role that recruitment rates likely play in oyster population recovery. If recruitment levels return to the average observed in 2004-2013, then oyster yields are likely to recover in about five years without any management action. If recruitment rates remain low (similar to 2012-2013), then the likelihood is high for a very slow oyster population recovery or even collapse. There are multiple factors that could lead to low recruitment at present or in the future, including:

1. Changes in $A_{\text {total }}$ caused by environmental factors and/or fishing. In this scenario, declines in the total area of oyster habitat would result in overestimates in oyster population levels based on extrapolation from DACS surveys from a small subset of oyster bars.

2. Removal of dead shell during the harvesting process, leading to a negative shell budget (shell losses exceeding deposition) and an overall decline in settlement area.

3. Irreversible increases in estimated relative natural mortality rate $(\mathrm{M})$ because of invasion or expansion in the system of oyster predators or diseases.

4. Nonstationarity in the stock-recruit relationship, meaning that uncorrelated random deviations from the mean stockrecruitment relationship can lead to very misleading assessments, while long-term recruitment trends because of habitat changes (i.e., settlement area, larval food supply) are masked. In traditional fisheries stock assessments, we sometimes attempt to deal with this structural problem by using virtual population analysis methods to back-calculate recruitment without assuming any underlying stockrecruitment relationship; however, we were unable to determine parameters for a virtual population analysis model with oyster populations because we did not know the age structure of the harvested population.

\section{DISCUSSION}

Factors contributing to the 2012 oyster population collapse based on available data

What led to the oyster population collapse in Apalachicola Bay in 2012-2013? Our results suggest that the 2012-2013 Apalachicola oyster population collapse was likely due to low recruitment and/or low sublegal survival rates. Our results warn that this decline may have resulted in or resulted from a decrease in larval settlement area (dead shell), which could severely retard population recovery or even send the stock into irreversible decline, depending on future recruitment and shell dynamics. Although the Apalachicola Bay oyster fishery has proven resilient over its $>150$-year history, this fishery now may be at a crossroads in terms of continued existence, and if recruitment levels remain low, then large-scale restoration programs may be necessary to avoid an irreversible collapse.

Perhaps the most important finding from our work is that none of the available data give superior estimates of historical exploitation rates fishing impacts. The sudden decline in Apalachicola Bay oyster landings in 2012 was preceded by several years of increasing harvest and effort. We initially suspected a case of overfishing led to the collapse of the oyster fishery; however, our analyses suggest a much more complex but classic problem in fish stock assessment: we can generally attribute the observed changes in relative abundance either to fishing or productivity changes, but we can never be sure which was more important without good independent data on absolute exploitation rates over time. With the data currently available for Apalachicola Bay, we cannot be sure whether we are dealing with a small oyster population that has been subject to strong fishing impacts or a larger population that has been subject to strong environmental influences that have impacted the long-term carrying capacity. In the latter case, the population may recover, but, if the long-term carrying capacity is reduced, it may not recover to the same historic levels.

\section{Factors likely not contributing to the 2012 oyster population collapse based on available data}

Our results are notable for what they did not find. Within the Apalachicola community there are two widespread hypotheses related to driving forces of the oyster fishery collapse. First, there is widespread concern that the oyster population collapse in 2012 was related to the Deepwater Horizon oil spill that occurred in March 2010. In a related project, a large number of sediment, water, and animal tissue samples were collected in 2012 by the University of Florida and no pollutants were detected (Havens et al. 2013, Camp et al. 2015). This corroborates results from sampling by state and federal agencies immediately after and in the years following the oil spill. Our model results suggest that the decline in sublegal oyster abundance in Apalachicola Bay did not begin until 2012, two years after the oil spill. To the best of our knowledge, the Apalachicola Bay oyster population was not directly impacted by oil or oil dispersants used during the 2010 Deepwater Horizon oil spill.

A second recent concern among the Apalachicola oyster fishing community and resource managers is the impact of low freshwater inputs into Apalachicola Bay from drought conditions within the Apalachicola-Chattahoochee-Flint basin. During 2011-2012, the Apalachicola-Chattahoochee-Flint basin experienced extensive drought (Palmer Drought Severity index of severe to extreme, https://www.drought.gov/drought/regional-programs/acfrb/acfrbhome), leading to low freshwater discharge into Apalachicola Bay and higher than normal salinity measures across several of the historically important oyster harvesting reefs (Havens et al. 2013). A series of previous studies have noted positive correlation between high-salinity drought conditions and oyster diseaserelated mortality (Petes et al. 2012), as well as complex relationships between estuarine freshwater discharge and oyster harvest (Wilber 1992, Turner 2006, Livingston 2015). We did not find correlations between Apalachicola River discharge measures (average monthly, total annual, total monthly, or coefficient of variation on annual discharge, mean seasonal, or total seasonal) and our estimated relative natural mortality rate (M) or oyster recruitment rates (example Fig. 6). The overall relationships between freshwater flows, drought frequency and severity, oyster recruitment, and harvest dynamics remain unclear, and this is an area of ongoing work.

\section{Management implications: oyster stock rebuilding scenarios}

A key finding from simulations of management scenarios is that oyster recruitment likely drives the Apalachicola Bay oyster fishery. We are uncertain as to the extent oyster recruitment can be influenced by management actions. This is seen in the relatively 
minor effect on fishery recovery time from effort reductions or shelling compared with the effect of differing recruitment averages. This uncertainty is largely because of a lack of understanding of the functional relationships between shelling and recruitment, and the inability of our assessment model to clearly define recent oyster harvest rates.

Fig. 6. Relative monthly recruitment for 1990-2012 (top panel) and relative natural mortality rate (M) for 1990-2012 (bottom panel) versus average monthly Apalachicola River discharge (Q) measured at the U.S. Geological Survey Sumatra gauge (02359170).
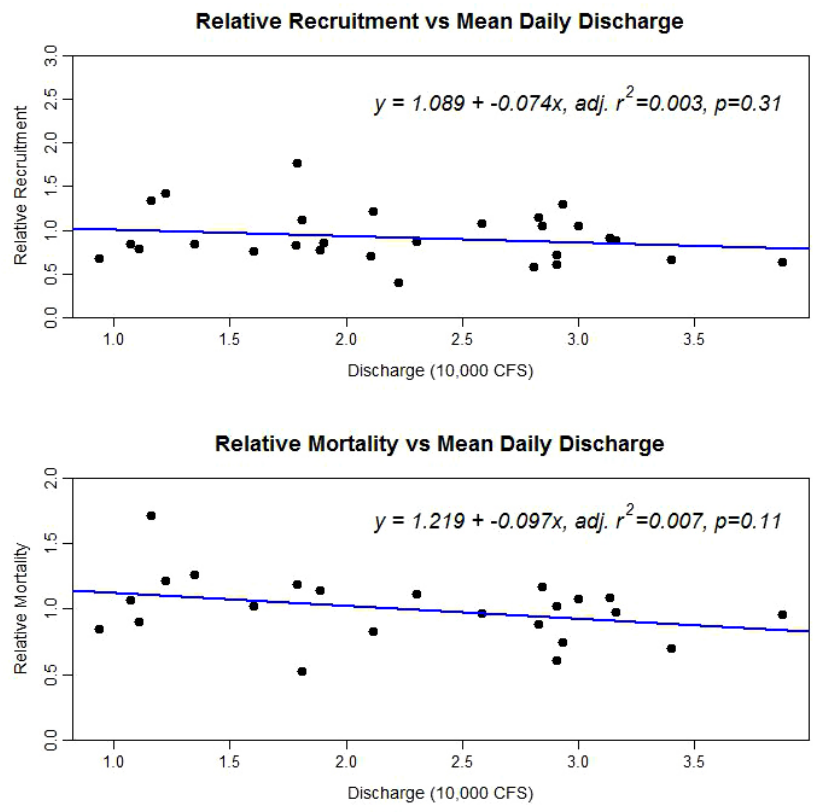

Although our model results suggest that the addition of shell as cultch material will have a minor effect on fishery recovery time under average recruitment levels, we conclude that shell addition may still be the best management action to follow. Shelling should not be expected to guarantee recovery of the fishery; but shell addition would be expected to reduce the risk of stock collapse in case low recruitment continues, while allowing for continued harvests. Adding shell material as cultch would be a critical management action if the current shell budget is deficient, with shell losses on existing reefs (from harvest-related discard, environmental disturbances, or other factors) exceeding deposition of new shell from the natural mortality of oysters. Although shell additions may restore settlement sites for oyster recruits, if oyster recruitment remains low for other reasons, then even large amounts of shelling may not lead to rapid oyster population recovery. However, based on our assessment model, shell addition is likely a better management action to achieve stated goals of oyster population and fishery recovery than fishery reductions or closures. Overall our results suggest that shell habitat as cultch should be as carefully managed as the oyster fishery for live oysters and that oyster shell material, in terms of available area, recruitment of new shell, and prevention of shell removal by harvest or storms, should be quantified and tracked.
Although recovery of the Apalachicola Bay oyster fishery may be possible without management actions, this recovery depends upon uncertain community dynamics. One uncertainty is how the fishing industry will respond over this recovery period. If the legal oyster biomass remains low, it is possible that fishers will not be willing to exert high fishing effort given costs associated with a day of fishing and low potential harvests. Such declines (voluntary or otherwise) in effort could hasten recovery; however, oyster prices are currently at near-record high levels, and alternative employment opportunities remain limited in this area. If prices and fishing effort remain high and increase, respectively, the chance of recovery could decrease as recovering oyster stocks are rapidly removed by harvest.

\section{Management implications: policy and research}

Our study suggests at least two policy issues that need to be addressed. First, it suggests that intense shelling (162 ha) should be immediately undertaken each year to counter the risk of irreversible fishery collapse, although we are uncertain at what density the shelling should occur to promote larval settlement and persistence of reef material. In 1986-1987, following 1985's Hurricane Elena, about 156 ha of oyster reef in Apalachicola Bay was successfully restored through a combination of restrictive harvest and shelling at a density of about $472 \mathrm{~m}^{3}$ of shell per hectare (Berrigan 1990). Within 18 months of completing this restoration, these oyster bars supported 587 oysters per $\mathrm{m}^{2}$ and more than 22 oysters per $\mathrm{m}^{2}$ of legal size $(76.2 \mathrm{~mm})$, leading Berrigan (1990) to conclude that the restoration costs were recovered after one harvest season from this area. Most shelling efforts in Apalachicola Bay have been at various densities and much smaller in scale, usually averaging about 40 ha in size, and these restoration efforts have varied widely in area and frequency in the last 20 years (Fig. 3e). Natural shell deposition occurs following oyster mortality events, which may help to partially explain the rapid oyster recovery in Apalachicola Bay following Hurricane Elena. Other than the Berrigan (1990) study, no oyster restoration efforts have been rigorously evaluated to inform future strategies, such as understanding the trade-off between shelling a small area at a high shell density versus shelling a larger area at a lower shell density. Because restoration costs have increased greatly since Berrigan (1990), this type of information is critical to informing effective restoration projects.

Second, actions (including shelling) should be designed to provide more opportunity for learning about the system (Camp et al. 2015). Uncertainty in shelling density is precisely linked to uncertainty in the total productive area of the current oyster fishery. Swift (1898) estimated the total area of commercially viable oyster bar in Apalachicola Bay to be about 4942 ha, whereas Rockwood et al. (1973, as cited in Whitfield and Beaumariage 1977) estimated about 2023-2428 ha in Apalachicola Bay in the early 1970s. More recent surveys of Apalachicola Bay (Twichell et al. 2010) have focused on the geologic features that support oyster reefs and do not provide density estimates comparable to those of earlier surveys. We assessed available geographic information system layers and estimated that the existing oyster reef area was about 4000 ha, but we do not have a good understanding of how the DACS oyster survey data apply to this area; i.e., we cannot extrapolate density estimates from DACS survey data to this entire area. Determining whether the total area $\left(\mathrm{A}_{\text {total }}\right)$ of commercially viable oysters has changed in Apalachicola Bay is a key area for future work. 
It is also uncertain what the impacts of fishery practices are on the persistence of shell material as cultch and sublegal oysters on oyster reefs. Swift (1897) warned of this potential for loss of shell material in his surveys of the Apalachicola Bay oyster fishery and suggested that "it is doubtful whether the law regarding the taking of small oysters and the culling of the oysters, especially the latter, are strictly complied with by the oystermen, yet it is of the greatest importance that they should realize that this law should be strictly obeyed if they wish to maintain the productiveness of the beds and thus insure themselves a livelihood in the future." Whether culling and discarding currently take place on the bars where the tonging occurs or in areas off of the bar is not known, but it is a sensible practice to only cull in the same location that tonging occurs. The key existing uncertainties in informing management actions regarding shelling density, productive fishery area, and availability and persistence of cultch material, as well as current harvest rates and effects of changing environmental conditions, disease, and oyster predator responses, all likely influence oyster recruitment levels that apparently drive the fishery. These uncertainties can be addressed, and their reduction is critical to informing decision making and bolstering the resilience of the Apalachicola Bay oyster fishery (Camp et al. 2015).

\section{CONCLUSION}

The Apalachicola Bay oyster fishery is currently at the lowest level observed in recent decades; however, this is not the first oyster population collapse in Apalachicola Bay (Swift 1898, Andree 1983, Berrigan 1990, Havens et al. 2013). For more than 120 years, various reports and workshops have repeated the same key uncertainties for oyster resources in Apalachicola Bay (i.e., unknown total area of oysters, unknown shell budget dynamics) and made the same types of management recommendations to address fundamental fishery practices, such as preservation and cultivation of shell substrate, seasonal closures, and size limits to protect oyster bars from being "overworked" (Table A2.4, Appendix 2). These recommendations often highlight recurring issues related to poor compliance with existing regulations, including high harvest rates of undersized oysters, harvest from closed areas, or culling and discarding that occur off of oyster bars. The results of our stock assessment model suggest that Apalachicola Bay oyster resources will respond positively to management actions, particularly actions that improve availability and area of shell substrate. Our simulation results suggest that if recruitment does not return to some long-term stationary level similar to past averages or if the resilience of the Apalachicola Bay oyster resource changes over time (Camp et al. 2015), then these types of management actions may not be effective.

A variety of state and federal restoration programs totaling more than U.S. \$10 million are currently committed to the Apalachicola oyster fishery and community. The oyster industry is likely to play a large role in determining how these funds are spent. The potential exists for restoration to be effective, given the success of prior oyster restoration efforts coupled with intensive fishery management for oyster resources in Apalachicola Bay (Berrigan 1990). Although restoration and management strategies are known, whether or not to follow these practices and how to use available restoration funds are choices to be made by the local community that are likely to determine the long-term viability of the Apalachicola Bay oyster fishery.
Responses to this article can be read online at: http://www.ecologyandsociety.org/issues/responses. $\mathrm{php} / 7827$

\section{Acknowledgments:}

We thank the University of Florida Institute of Food and Agricultural Sciences and Florida Sea Grant for funds to support the completion of this project. We thank Susan Marynowski for editorial assistance, Amanda Carr for art work, and numerous colleagues and cooperators for comments on earlier drafts.

\section{LITERATURE CITED}

Andree, S., editor. 1983. Apalachicola oyster industry: conference proceedings. Report No. 57. University of Florida Sea Grant Program, Gainesville, Florida, USA.

Beck, M. W., R. D. Brumbaugh, L. Airoldi, A. Carranza, L. D. Coen, C. Crawford, O. Defeo, G. J. Edgar, B. Hancock, M. C. Kay, H. S. Lenihan, M. W. Luckenbach, C. L. Toropova, G. F. Zhang, and X. M. Guo. 2011. Oyster reefs at risk and recommendations for conservation, restoration, and management. BioScience 61:107-116. http://dx.doi.org/10.1525/bio.2011.61.2.5

Berrigan, M. E. 1990. Biological and economical assessment of an oyster resource development project in Apalachicola Bay, Florida. Journal of Shellfish Research 9:149-158.

Borsje, B. W., B. K. van Wesenbeeck, F. Dekker, P. Paalvast, T. J. Bouma, M. M. van Katwijk, and M. B. de Vries. 2011. How ecological engineering can serve in coastal protection. Ecological Engineering 37:113-122. http://dx.doi.org/10.1016/j.ecoleng.2010.11.027

Camp, E. V., W. E. Pine III, K. Havens, A. S. Kane, C. J. Walters, T. Irani, A. B. Lindsey, and J. G. Morris. 2015. Collapse of a historic oyster fishery: diagnosing causes and identifying paths toward increased resilience. Ecology and Society 20(3):45. http:// dx.doi.org/10.5751/ES-07821-200345

Coen, L. D., R. D. Brumbaugh, D. Bushek, R. Grizzle, M. W. Luckenbach, M. H. Posey, S. P. Powers, and S. G. Tolley. 2007. Ecosystem services related to oyster restoration. Marine Ecology Progress Series 341:303-307. http://dx.doi.org/10.3354/meps341303

Dugas, R. J., E. A. Joyce, and M. E. Berrigan. 1997. History and status of the oyster, Crassostrea virginica, and other molluscan fisheries of the U.S. Gulf of Mexico. Pages 187-210 in C. L. MacKenzie, Jr., V. G. Burrell, Jr., A. Rosenfield, and W. L. Hobart, editors. The history, present condition, and future of the molluscan fisheries of North and Central America and Europe. Volume 1: Atlantic and Gulf Coasts. NOAA Technical Report NMFS 127. U.S. Department of Commerce, Woods Hole, Massachusetts, USA.

Havens, K., M. Allen, E. Camp, T. Irani, A. Lindsey, J. G. Morris, A. Kane, D. Kimbro, S. Otwell, B. Pine, and C. Walters. 2013. Apalachicola Bay oyster situation report. Technical Publication 201. University of Florida Sea Grant, Gainesville, Florida, USA.

Hayes, P. F., and R. W. Menzel. 1981. The reproductive cycle of early setting Crassostrea virginica (Gmelin) in the northern Gulf of Mexico, and its implications for population recruitment. Biological Bulletin 160:80-88. 
Livingston, R. J. 1991. Historical relationships between research and resource management in the Apalachicola River estuary. Ecological Applications 1:361-382. http://dx.doi.org/10.2307/1941897

Livingston, R. J. 2002. Trophic organization in coastal systems. CRC, Boca Raton, Florida, USA. http://dx.doi.org/10.1201/978$\underline{1420040852}$

Livingston, R. J. 2015. Climate change and coastal ecosystems: long-term effects of climate and nutrient loading on trophic organization. CRC, Boca Raton, Florida, USA.

Livingston, R. J., X. Niu, F. G. Lewis, III, and G. C. Woodsum. 1997. Freshwater input to a gulf estuary: long-term control of trophic organization. Ecological Applications 7:277-299. http:// dx.doi.org/10.1890/1051-0761(1997)007[0277:FITAGE]2.0.CO;2

MacKenzie, C. L. 1996. History of oystering in the United States and Canada, featuring the eight greatest oyster estuaries. Marine Fisheries Review 58:1-78.

Petes, L. E., A. J. Brown, and C. R. Knight. 2012. Impacts of upstream drought and water withdrawals on the health and survival of downstream estuarine oyster populations. Ecology and Evolution 2:1712-1724. http://dx.doi.org/10.1002/ece3.291

Seavey, J. R., W. E. Pine III, P. Frederick, L. Sturmer, and M. Berrigan. 2011. Decadal changes in oyster reefs in the Big Bend of Florida's Gulf Coast. Ecosphere 2:art114. http://dx.doi. org/10.1890/es11-00205.1

Swift, F. 1897. Survey of the oyster regions of St. Vincent Sound, Apalachicola Bay, and St. George Sound, Florida. U.S. Commission of Fishes and Fisheries, Extracted from Report of Commissioner for 1896. U.S. Commission of Fishes and Fisheries, Washington, D.C., USA.

Swift, F. 1898. The oyster-grounds of the west Florida coast: their extent, conditions, and peculiarities. Pages 185-187 in Proceedings and Papers of the National Fishery Congress, Tampa, Florida, January 19-24, 1898. U.S. Commission of Fish and Fisheries, Washington, D.C., USA.

Turner, R. E. 2006. Will lowering estuarine salinity increase Gulf of Mexico oyster landings? Estuaries and Coasts 29(3):345-352. http://dx.doi.org/10.1007/bf02784984

Twichell, D., L. Edmiston, B. Andrews, W. Stevenson, J. Donoghue, R. Poore, and L. Osterman. 2010. Geologic controls on the recent evolution of oyster reefs in Apalachicola Bay and St. George Sound, Florida. Estuarine, Coastal and Shelf Science 88:385-394. http://dx.doi.org/10.1016/j.ecss.2010.04.019

Whitfield, W. K., Jr., and D. S. Beaumariage. 1977. Shellfish management in Apalachicola Bay: past-present-future. Pages 130-140 in R. J. Livingston and E. A. Joyce, Jr., editors. Proceedings of the Conference on the Apalachicola Drainage System. Florida Marine Resource Publication No. 26. Florida Department of Natural Resources, Tallahassee, Florida, USA.

Wilber, D. H. 1992. Associations between freshwater inflows and oyster productivity in Apalachicola Bay, Florida. Estuarine, Coastal and Shelf Science 35:179-190. http://dx.doi.org/10.1016/ $\underline{\mathrm{s} 0272-7714(05) 80112-\mathrm{X}}$
Wilberg, M. J., M. E. Livings, J. S. Barkman, B. T. Morris, and J. M. Robinson. 2011. Overfishing, disease, habitat loss, and potential extirpation of oysters in upper Chesapeake Bay. Marine Ecology Progress Series 436:131-144. http://dx.doi.org/10.3354/ $\underline{\text { meps09161 }}$ 
Appendix 1. Age-structured oyster stock assessment model.

Please click here to download file 'appendix1.xlsx'. 


\section{Appendix 2}

Age-structured population dynamics model development

\section{Growth}

In our age-structured model (Appendix 1), growth of oysters is first described using standard von Bertalanffy growth parameters (Walters and Martell 2005). For Apalachicola Bay, we estimated these parameters using incremental growth measurements obtained from oyster growth experiments conducted by the Florida Department of Environmental Protection (DEP) during 2004-2009 (J. Harper, DEP, personal communication). We then used the Ford-Brody representation of growth (Equation 2), which is a relatively simple bioenergetics model derived from the von Bertalanffy assumptions that: (1) anabolic (feeding) rates vary as the 2/3 power of body weight, (2) catabolic (metabolic) rates are proportional to body weight, and (3) body length varies as the 1/3 power of body weight. The Ford-Brody $\alpha$ parameter (Equation 3 ) can be expressed in terms of the asymptotic maximum body length $\mathrm{L}_{\infty}$ (Equation 4). As noted by Walters and Post (1993), $\mathrm{L}_{\infty}$ represents effects of both feeding and metabolic rates, and is likely to vary inversely with population density. Both feeding and metabolic rates are likely to vary with water temperature, but lead to the same $\mathrm{L}_{\infty}$ if both rates vary with the same $\mathrm{Q}_{10}$ or Arrhenius power of temperature. Using these relationships, we expect $\mathrm{L}_{\infty}$ to vary with population density but not temperature, and $\rho$ (the slope of the Ford-Brody plot) to vary only with temperature. Hence we assume $\rho_{m}=e^{-K m}$ to vary in a sinusoidal pattern; variation in $K_{m}$ is due to variation in monthly average temperature, and $\alpha$ varies both with density and monthly temperature. In the von Bertalanffy model, feeding or filtering rate is assumed to vary as the square of body length.

The use of monthly time steps in our age-structured model allows for the incorporation of seasonal variation in growth (Appendix Figure A2.1). In Florida, there is wide divergence in reported oyster growth rates with estimated age $(a)$ of recruitment to the legal size $(76.4 \mathrm{~mm})$ ranging from about $a=7$ months (Ingle and Dawson 1952) to $a=15$ months or more (L. Sturmer, University of Florida, unpublished information). Growth has also been reported to be seasonal (Ingle and Dawson 1952; Hayes and Menzel 1981) with average growth rates of about $0.05 \mathrm{~mm} /$ day in the winter and $0.15 \mathrm{~mm} /$ day in the summer. We examined a large sample of individual Apalachicola Bay oyster growth curves from 2004-2009 (data from J. Harper, DEP, personal communication) and did not find evidence for strong seasonality in growth. We fit these growth measurements to the Ford-Brody growth model and found best fit with weak seasonal growth (Appendix Figure A2.1) and constant $\mathrm{L}_{\infty}=90 \mathrm{~mm}$ and $\mathrm{K}=0.1 / \mathrm{month}$. It is unclear from the literature how strong density-dependent effects on oyster growth might be, and our attempts to include density dependent effects on Apalachicola Bay oyster growth did not improve model fit.

\section{Survival}

In our population dynamics model, we assume that survival rates $S_{a, t}(1=$ natural mortality) in Equation 1 were assumed to vary with oyster age and body length, according to the Lorenzen survival function (mortality rate inversely proportional to body length). We assumed a base natural mortality rate (around $0.1 /$ month) for larger oysters that had reached near asymptotic length and applied an annual relative mortality rate scaler $\left(\mathrm{P}_{\mathrm{y}}\right.$, varying around 1.0) to represent changes in natural mortality rate (e.g., from salinity, predation, disease, etc.). Based on field 
observations, the net mortality rate of oysters in a dense "clump" may be very low and the oyster populations persist for a long time. This is accounted for in our model in Equation 5 which can predict a "stagnant" high density situation where $\mathrm{L}_{\infty, \mathrm{t}}$ has been severely reduced through competition when most oysters have reached this length or larger.

We assumed that the vulnerability of oysters to harvesting ( $\mathrm{v}_{\mathrm{a}, \mathrm{t}}$ in Equation 1) varies with body length and the legal minimum length for harvest (in Apalachicola Bay, $\mathrm{L}_{\text {legal }}=76.2 \mathrm{~mm}$ ) according to a logistic function that represents variation in size at age around the mean length $\mathrm{L}_{\mathrm{a}, \mathrm{t}}$ (Equation 6). Monthly exploitation rates $U_{t}$ are predicted in our model from fishing efforts using a standard Baranov catch equation (Equation 7; Hilborn and Walters 1992). This catch equation assumes density dependence and variation in vulnerable biomass in catchability $(q)$ according to a type II functional response (Equation 8). Note that Equation 8 can represent combined effects of nonrandom searching for oysters by fishermen, handling and processing time, and caps on daily harvests by regulation or orders from wholesale oyster dealers per oyster license holder.

In the population dynamics model, information on annual oyster recruitment is required to drive initial oyster year class size in each year. For Apalachicola bay, we developed a standardized index of oyster recruitment using fisheries independent survey data of oysters by 5-mm size classes collected by the Florida Department of Agriculture and Consumer Services (DACS) on the major commercial fishing reefs in Apalachicola Bay (available from 1990-2013). As a tong fishery, a fishing trip in Apalachicola Bay consists of a number of oyster tong lifts that each "sweep" some area $a_{\text {lift }}$ of the bottom. From our assessment of the fisheries independent survey data, it appears that when fishing effort is measured by the number of oyster fishing trips annually, $q$ varies as predicted by Equation 8 . The DACS survey data also provided annual estimates of mean legal oyster biomass per unit area $\mathrm{D}_{\text {year }}$. The catch per trip should thus vary as catch-per-unit-effort $(C P U E)=a_{\text {lift }} \times$ number of lifts per trip $x \mathrm{D}_{\text {year }}$. If lifts per trip were constant and lift locations were random with respect to fine-scale variation in oyster densities, CPUE should be proportional to $\mathrm{D}_{\text {year }}$ (i.e., $q$ measured as $\mathrm{a}_{\text {lift }} \mathrm{x}$ number of lifts per trip should be constant). However, when we plot the observed ratio of CPUE to mean DACS density, we see instead that the apparent $q$ has increased considerably when densities have been low (Appendix Figure A2.2). Apalachicola oyster fishermen have told us that they do indeed stay out longer and make more lifts when oyster abundance is low, and typically end each trip when their catch approaches trip limits imposed by regulations or daily limits based on market orders from dealers.

\section{Recruitment}

Monthly recruitment $\mathrm{N}_{1, \mathrm{t}}$ (Equation 9) to the population is predicted as a function of larval oyster settlement (Equation 10,10a) and available shell material with a density-dependent mortality function applied during the first month of settlement to match observed survival patterns (Equation 11). We examined an alternative model for larval settlement where base settlement rate was made a power function of the relative spawning biomass index $\mathrm{SB}_{\mathrm{t}}$ (Equation 10a).

\section{Shell Accumulation}

A key aspect of our population dynamics model is the development of an accounting and prediction system for oyster shell biomass and the explicit linkage in our model between oyster recruitment, oyster mortality rates, and availability of shell material for spat settlement 
(Equations 9-13). This is an original contribution. In our model, if shell persistence (shell survival $)$ is high $\left(S_{\text {shell }}=0.99\right)$ this implies slow deterioration in the shell substrate base available for oyster settlement and recruitment. Under sustainable oyster harvesting regimes, the suitable shell area $\mathrm{AS}_{\mathrm{t}}$ is predicted in our shell budget to approach a nonzero equilibrium value (i.e., shell "recruitment" exceeds removals from harvest). However, the possibility of long term deterioration in oyster population carrying capacity would result if abundances $\mathrm{N}_{\mathrm{a}, \mathrm{t}}$ are severely reduced through harvesting, leading to declines in $\mathrm{AS}_{\mathrm{t}}$. This suggests that there is a critical oyster stock size below which the oyster population will tend toward zero unless recruitment onto the oyster bars is assumed to be supported by adult oysters invulnerable to the fishery (the power function for larval settlement $\mathrm{LS}_{\mathrm{t}}$ in equation $10 \mathrm{a} \beta<1.0$ ). Early attempts to fit the model by allowing $\beta$ to vary always led to $\beta=0$ (similar to Equation 10), but full use of both oyster harvest and relative abundance information suggests the opposite result: that $\beta$ is larger and generally approaches the constraint $\beta=1$. In our model, Equation 12 predicts that on average the ratio of dead shells to total live oysters, AS/N, should be near $\left(1-S_{\text {live }}\right) /\left(1-S_{\text {shell }}\right)$, where $S_{\text {live }}$ is the average of $S_{a, t}$ weighted by $N_{a, t} / N$. From field observations we have seen highly variable AS/N, but typically we see ratios near 1.0, where the number of recently dead shells is about equal to the number of live oysters. This implies $S_{\text {shell }}$ should be about equal to $S_{\text {live }}$, in the range 0.8-0.9. For our Apalachicola Bay analysis, we assumed a relatively conservative value 0.8 for the analysis. Our model assumes an exponential form of the larval production rate proportional to live biomass, which implies an overall long term Ricker stock-recruitment relationship (Hilborn and Walters 1992) for the population. This allows for depensatory decrease in recruitment at low oyster population stock sizes due to the shell area dynamics factor $\mathrm{AS}_{\mathrm{t}}$ (Equation 13).

\section{Parameter Scaling}

We used scaling parameters (i.e., $\mathrm{k}_{\text {growth }}$ ) to link oyster and fishery rate processes (growth, catchability, biomass) with oyster abundance as measured by the sum of squared lengths and biomass (Equations 14-15). Appropriate values for these parameters depend on the units of measurement of length, and scaling of overall population size so as to match historical abundance and catch data. This scaling is simplified by specifying an overall average natural recruitment rate $R_{o}$ and corresponding Botsford incidence functions that sum up age specific quantities weighted by survivorship to age assuming equilibrium (Walters and Martell 2004, Box 3.1, page 56) for natural survivorships to age $\mathrm{x}$ natural age-specific quantities $\left(\mathrm{L}^{2}, \mathrm{~W}\right.$; Equations 16-22). In our model, as $\mathrm{R}_{\mathrm{o}}$ is varied by the user or by Solver in Excel (Microsoft Corporation, Redmond, Washington), the scaling parameters are varied so as to predict growth and survival rates that will make $R_{o}$ close to a stable equilibrium value without harvesting. That is, the model predicts base numbers and sizes at age $\mathrm{N}_{\mathrm{a}, 0}$ by assuming $\mathrm{N}_{\mathrm{a}, 0}=\mathrm{R}_{\mathrm{o}} \mathrm{l}_{\mathrm{a}, 0}$ where $\mathrm{l}_{\mathrm{a}, 0}$ is natural survivorship to age $a$, given a base or natural growth curve $\mathrm{L}_{\mathrm{a}, 0}$ with associated base predictions of $\mathrm{M}_{\mathrm{a}, \mathrm{o}}$. These base numbers and sizes are used in the model to predict base values for the sums over ages that appear in the various dynamic equations. The dynamic equations are then solved for the scaling parameters $(k)$ given these base values. Given the season and density effects parameterized in the model and observed in the data, this solution for the $k$ values is not exact but is sufficient to avoid strong transient changes as the model dynamics "spin up" over time.

To further simplify the parameter scaling in our stock assessment model, key quantities like maximum oyster catchability $\mathrm{q}_{\max }$ and body size $\mathrm{L}_{\infty \mathrm{max}}$ were assumed as ratios to either base unfished values or to likely values at some sustainable fished equilibrium. We specified a base 
exploitation rate $\mathrm{U}_{\mathrm{o}}$ in which case the population is assumed to have been fished at this rate (and to be near equilibrium with respect to it) for enough time for abundances and sizes to have reached equilibrium. These initial equilibrium values are used to set $\mathrm{N}_{\mathrm{a}, 1}$ (numbers at age in the first simulation month) and catchability scaling parameter $\mathrm{k}_{\mathrm{q}}$ that will give a catchability $\mathrm{q}_{\mathrm{o}}$ that insures $\mathrm{U}_{\mathrm{t}}=\mathrm{U}_{\mathrm{o}}$ when effort is at its initial time value $\mathrm{E}_{1}$.

\section{Alternative Model Formulation to Check Model Assumptions and Predictions}

We were concerned that the Ricker functional form for density dependent early survival in our model may have a dome shape, and hence may provide overly optimistic predictions about recruitment changes when oyster stock size is reduced. To check this possibility, we ran the model with an alternative stock-recruitment relationship of Beverton-Holt form (described in Equations 23-25, final form Equation 26). This alternative model was derived by assuming that larval settlement $\mathrm{LS}_{\mathrm{t}}$ has a mass-action relationship to both relative egg production (relative spawning biomass index $\mathrm{SB}_{\mathrm{t}}$ ) and relative effective shell settlement area $\mathrm{A}_{\text {set. }}$.

\section{Equilibrium Analysis Using Growth Type Group Splitting of Recruitment}

We were also concerned that the population dynamics model could give misleading predictions of length distribution patterns if the length distribution predictions are based on treating the length distribution at each age as "regenerating" each month by having constant standard deviation independent of harvesting effects (Walters and Martell 2004). In reality, faster growing individuals from each cohort will reach legal size sooner and be removed by fishing, which progressively distorts the length distribution for each age. The distortion could be represented by dividing each cohort into a set of growth types, and tracking size and survival (natural and fishing) separately for each group. However, this computation would result in extremely complex monthly accounting unless it was used simply to predict average or equilibrium length distributions over periods of stable growth and exploitation rate in a growth type group (GTG) model structure (Walters and Martell 2004, Box 5.3, p. 121). Using this simplified method, equilibrium length frequency predictions were made for five-year periods from 1990-2012.

The equilibrium GTG predictions were constructed by first dividing a typical cohort of $\mathrm{N}=1.0$ recruits into 21 growth types $g$, each initialized at 1 month age to $\mathrm{N}_{\mathrm{g}, 1}=\mathrm{p}(\mathrm{g})$ recruits where $\mathrm{p}(\mathrm{g})$ is the proportion of recruits assigned to group $g$. All groups were assumed to have the same von Bertalanffy $\mathrm{K}$ value, and distinct maximum lengths $\mathrm{L}_{\infty}(\mathrm{g})$ given by $\mathrm{L}_{\infty}(\mathrm{g})=\mathrm{L}_{\infty}[1+\mathrm{CV} \Delta(\mathrm{g}-11)]$ where $\mathrm{CVL}_{\infty}$ is the standard deviation of $\mathrm{L}_{\infty}$ among individuals (we assumed $\mathrm{CV}=0.1$ ). We also assumed that $\Delta$ is the standard normal distribution increment between groups and we set $\Delta$ such that the groups vary in $\mathrm{L}_{\infty}$ over two standard deviations from average, with $g=11$ representing the average group. Applying the von Bertalanffy growth equation by $g$ and age results in a $21 \mathrm{x}$ 36 matrix $\mathrm{L}_{\mathrm{g}, \mathrm{a}}$ of predicted lengths at age, we then applied the basic survival equation (Equation 1) to each group over age to predict the $21 \times 36$ matrix $\mathrm{N}_{\mathrm{g}, \mathrm{a}}$, using the Lorenzen size-dependent survival rate for each $\mathrm{L}_{\mathrm{g}, \mathrm{a}}$ (Equation 5) and vulnerability $\mathrm{v}_{\mathrm{g}, \mathrm{a}}$ to fishing set at 0.0 for predicted lengths at age $<75 \mathrm{~mm}$ and at 1.0 for lengths $75 \mathrm{~mm}$ and larger (approximate legal size of harvest in Florida). Finally, the equilibrium length distribution was obtained by simply summing all the $\mathrm{N}_{\mathrm{g}, \mathrm{a}}$ by 5-mm length bins, with length bin assignment determined by the $\mathrm{L}_{\mathrm{g}, \mathrm{a}}$ lengths. 
Our basic approach to estimate as many of the model parameters as possible involved (1) estimating oyster growth and recruitment timing parameters from independent data sources and inputting these values, then (2) fitting the model to a set of time series data using a "stock synthesis" approach where the model equations are solved over time given only initial stock structure, effort time series, and relative recruitment and mortality time series. This is a harsh test of the model structure, since the equations could easily diverge greatly from patterns evident in the data if the model parameter values were far off.

Three time series were available for estimation of model parameters for the Apalachicola Bay oyster population: (1) monthly meat weight of oysters landed $\mathrm{C}_{t}$ for 1986-2012, (collected by FWC), (2) monthly fishing efforts (daily fishing trips) $\mathrm{E}_{\mathrm{t}}$ for these same months (collected by FWC), and (3) annual survey estimates for 1990-2012 of absolute density of oysters (numbers $/ \mathrm{m}^{2}$ ) by 5-mm size increments, from 10-40 $0.25 \mathrm{~m}^{2}$ quadrats per year (collected by DACS). We aggregated the DACS survey densities by size to numbers of sublegal (20-75 mm) and legal (> $75 \mathrm{~mm}$ ) oysters per $\mathrm{m}^{2}$. The more detailed 5-mm interval length distributions were compared to model-predicted distributions only after fitting, since these detailed distributions are "contaminated" by interannual changes in seasonal timing of recruitment not fully captured in the basic model.

Unfortunately, the DACS data cannot be used directly to estimate total population size, since the total oyster bar area to which the sampled densities apply is not known. Estimates of oyster bar area based on geological sampling (Twichell et al. 2006, 2010) and available GIS layers (Apalachicola National Estuarine Research Reserve; January 2013) suggest a total area $A_{\text {total }}$ of at least $40 \mathrm{~km}^{2}$, whereas the DACS density estimates and fishery catch data imply that the observed catches might be coming from as little as $2-4 \mathrm{~km}^{2}$ of productive bottom. In directly comparing the DACS data to catches, we noted a useful conversion factor: a DACS legal density (> $75 \mathrm{~mm}$ ) of $30 / \mathrm{m}^{2}$ corresponds to a live weight harvestable biomass of $0.45 \mathrm{~kg} / \mathrm{m}^{2}\left(1 \mathrm{lb} / \mathrm{m}^{2}\right)$, so densities of $30 / \mathrm{m}^{2}$ represent about $453,492 \mathrm{~kg} / \mathrm{km}^{2}\left(1\right.$ million $\left.\mathrm{lb} / \mathrm{km}^{2}\right)$.

Also unfortunately, only a few of the DACS sampling areas have been visited consistently since 1990 (Table 1) and these areas are known only based on the name of the oyster bar and not a specific location on the bar. This creates a need to estimate missing area-year data combinations based on persistent differences among areas and shared temporal patterns (Equation 27). Fishery CPUE $\left(\mathrm{C}_{\mathrm{t}} / \mathrm{E}_{\mathrm{t}}\right)$ has varied less than the DACS legal density estimates $\mathrm{DL}_{\mathrm{y}}$ over time (Appendix Figure A2.2), suggesting as indicated above that CPUE has been strongly hyperstable (i.e., CPUE does not decline as fast as abundance).

Based on our growth assessments, the majority of sublegal oysters $\left(\mathrm{DS}_{\mathrm{y}}\right)$ counted in any year of the DACS survey data probably did not become legal until the next year (average sublegal length was about $40 \mathrm{~mm}$, implying about a year to reach legal length). This suggests that the ratio $\mathrm{DL}_{\mathrm{y}+1} / \mathrm{DS}_{\mathrm{t}}$ is a reasonable estimator of the annual survival rate of sublegal oysters and $\mathrm{M}=-$ $\ln \left(\mathrm{DL}_{\mathrm{y}+1} / \mathrm{DS}_{\mathrm{t}}\right) / 12$ is a reasonable estimator of the monthly natural mortality rate of sublegal oysters. Indeed, we would not even attempt to estimate the annual relative mortality multipliers $\mathrm{P}_{\mathrm{y}}$ in Equation 5 if it were not for the direct information about annual carryover rates evident in the DACS data. The most realistic average mortality rates were obtained when the model $\mathrm{M}_{\mathrm{o}}$ value was set to $0.1 /$ month (Appendix Table 3). 
Population Dynamics Model Estimation Procedure for Apalachicola Bay Oyster Fishery We maximized a concentrated log likelihood function for the time series data (Equation 28) using Solver, by varying the following parameters:

$$
\left\{\mathrm{R}_{\mathrm{o}}, \mathrm{l}_{\mathrm{o}}, \mathrm{U}_{\mathrm{o}}, \mathrm{q}_{\max }, \mathrm{M}_{\mathrm{o}}, \mathrm{P}_{1986}-\mathrm{P}_{2012}, \mathrm{RY}_{1986}-\mathrm{RY}_{2012}\right\}
$$

where $R_{o}$ sets the basic simulated population scale, $1_{0}$ determines resilience (how low the population can be driven before recruitment fails), base exploitation rates $U_{o}$ and $q_{\max }$ determine average monthly exploitation rate $U_{t}$ given effort $E_{t}$ and harvestable biomasses $B_{t}, P_{y}$ drives interannual variation in natural mortality rate, and $\mathrm{RY} \mathrm{y}_{\mathrm{y}}$ drives interannual changes in relative recruitment rate. Note that we would not ordinarily try to estimate both fishing $\left(\mathrm{U}_{\mathrm{o}}, \mathrm{q}_{\mathrm{max}}\right)$ and natural mortality $\left(\mathrm{M}_{\mathrm{o}}\right)$ rates at the same time, but having sublegal and legal density estimates from the DACS data makes this possible. As recommended by Walters and Ludwig (1994), $\mathrm{SS}_{\mathrm{DACS}}$ (Equation 29) is evaluated at the conditional maximum likelihood estimate of $\mathrm{q}_{\mathrm{s}}$. As an alternative to this SS that assumed $\mathrm{q}_{\mathrm{s}}$ to be unknown, we note that given the DACS units of measurement (counts $/ \mathrm{m}^{2}$ ), $\mathrm{q}_{\mathrm{s}}$ can be interpreted as $1 / \mathrm{A}_{\text {total }}$, where $\mathrm{A}_{\text {total }}$ is the total productive area of the fishery. For some fitting trials, we froze $A_{\text {total }}$ to various reasonable values, ranging from $2.0 \mathrm{~km}^{2}$ to $10 \mathrm{~km}^{2}$. The "penalty" terms for recruitment and survival anomalies (Equations 30 and 31) are the same as assuming $R Y_{y}$ and $P Y_{y}=e^{\xi y}$, where $\xi_{y}$ is assumed to be normally distributed with mean zero.

The estimation criterion defined by Equation 28 requires an estimate of the four $\sigma^{2}$ variances: catch, survey abundance, recruitment, natural mortality. However, we were unsure how to estimate these variances, or what to assume about their structure. We initially attempted to estimate them as additional unknown parameters [by changing from SS/variance to $(\mathrm{n} / 2) \ln (\mathrm{SS})$ terms in Equation 28, thus evaluating the normal log likelihood terms at their conditional maximum likelihood variance estimates], but this led to unrealistically high estimates of $\mathrm{RY}_{\mathrm{y}}$ variation and no variation in $\mathrm{P}_{\mathrm{y}}$, basically "ignoring" evidence of mortality variation in the DACS data in favor of fitting the catch data more precisely. To force the model to better fit the DACS data, we assumed relatively high variance in the catch $\sigma_{C}^{2}=1.0$, and low DACS variance $\sigma_{\text {DACS }}^{2}=0.04$ based on coefficient of variation of the annual abundance estimates of around 0.2 based on observed variation in densities among bars sampled each year. We also tried various combinations of values for $\sigma_{R Y}^{2}$ and $\sigma_{P}^{2}$, generally in the range $0.1-1.0$, to represent alternative hypotheses about how much of the observed variation has been due to recruitment versus survival variation.

\section{Age-structured Population Model Results}

Model estimates of natural mortality $\left(\mathrm{M}_{\mathrm{o}}=0.095 / \mathrm{month}\right)$ and exploitation rates (averaging 5\%$10 \%$ per month) from our stock assessment model are quite reasonable and the $\mathrm{q}_{\mathrm{s}}$ estimate implies a productive area of around $2 \mathrm{~km}^{2}$. When we used the Beverton-Holt formulation for recruitment (Equation 26), best fits were obtained at unrealistically high unfished recruitments $R_{o}$ (huge productive area), low productivity $(\alpha)$, and unrealistically low exploitation rates $U_{t}$. That is, the Ricker stock-recruitment formulation indicated a small, productive stock while the Beverton-Holt indicated a large, unproductive one.

The DACS data represents the best available information on trends in abundance and oyster size composition of areas fished. Because of uncertainty in the total area $\left(\mathrm{A}_{\text {total }}\right)$ of oysters to which 
the DACS surveys apply, we systematically varied $A_{\text {total }}$ from low to high while allowing all other model parameters in the model to vary. This was done to try and determine whether the fishery was supported from a small highly productive oyster population or a large lowproductivity oyster population. It resulted in almost identical fits to the catch and survey data from either the small productive or large unproductive oyster stock scenario (sums of squares based on the catch data or the DACS survey data, Equation 23). For both scenarios (small productive or large unproductive) the best model fits (lowest sums of squares, Equation 23) show a substantial increase in the Apalachicola Bay oyster population from 1990 until about 2000, then a persistent decline (Appendix Figure A2.3). Estimated exploitation rates during this time period of increasing population were lower during the years 1990-2000 than in recent years when oyster populations have declined (Figure 4; Appendix Figure A2.3). How were the same results and model fits found from models with very different $A_{\text {total }}$ ? For the large, low productivity stock scenario (high values of $A_{\text {total }}$ ) the best model fit was made by estimating high $\mathrm{M}_{\mathrm{o}}$ and by attributing the patterns in oyster abundance and landings mainly to large recruitment and mortality anomalies $\left(\mathrm{SS}_{\mathrm{P}}, \mathrm{SS}_{\mathrm{RY}}\right.$ components of the likelihood function, Equation 23$)$. For the small, highly productive stock, the patterns in oyster abundance and landings are attributed by the model more to effects of fishing (i.e., estimating low exploitation rates during the mid-1990s, much higher exploitation rates at present), leading to considerably smaller recruitment and natural mortality anomalies and hence lower $\mathrm{SS}_{\mathrm{P}}, \mathrm{SS}_{\mathrm{RY}}$ in the likelihood function (Equation 23).

We had hoped that close examination of the DACS length frequency data for legal oysters would demonstrate changes in exploitation rate, at least between the lower exploitation period of the mid-1990s compared to the higher exploitation from about 2008-2013, through reduced relative abundance of larger oysters in the high exploitation period (Figures 4 and Appendix Figure A2.3). However, the data show no such pattern; if anything they seem to support the hypothesis that monthly exploitation rates have never been high enough to severely distort the size distribution based on the available data. As an example, a comparison of predicted and observed length frequencies for oysters by year suggests either no change, or possibly that survival rates to larger sizes were lower in the early to mid-1990s than indicated by model estimates of exploitation rates (Appendix Figures A2.4 and A2.5, see 1992-99 as examples where observations are lower than predictions for legal size oysters).

Comparison of the full model length distributions to DACS length frequencies (Appendix Figure A2.5) shows that the model does not correctly predict the observed sublegal $(<75 \mathrm{~mm})$ size distribution in late fall for most years. The model predicts a more pronounced peak in the size distribution near $40 \mathrm{~mm}$ (Appendix Figure A2.5, solid line) than was observed in most years (Appendix Figure A2.5, dots), indicating a wider spread in settlement timing than assumed. For recent years the observed length distribution has peaks at smaller sizes (15-20 $\mathrm{mm})$, presumably representing later seasonal timing of successful settlement than assumed in the model. The late settlement years in the DACS data (1993, 1995, 2000, 2002, 2005-2011) are not obviously correlated with any known environmental factor such as Apalachicola River discharge (average monthly, total annual and total monthly, CV on annual discharge, mean seasonal, or total seasonal). We could have forced the model to fit the juvenile patterns more closely by estimating a set of nuisance parameters representing annual recruitment timing variation, but this would not change the model's basic predictions about abundance trends and harvest impacts, and would instead give a false impression about the model's precision in explaining observed data. 
Growth Type Group Model Results

The equilibrium GTG model gives average exploitation rates by 5 -year period similar to those resulting from fitting the age-structured model with $\mathrm{A}_{\text {total }}=5 \mathrm{~km}^{2}$ (Appendix Table A2.2), provided the natural mortality parameter $\mathrm{M}_{\mathrm{o}}$ is set to $0.1\left(\mathrm{M}=\mathrm{K}\right.$ assumption, also best $\mathrm{M}_{\mathrm{o}}$ from that same age-structured model fit). These fits were obtained by visual comparison of the model and observed legal length proportions (Appendix Figures A2.4 and A2.5). For alternative estimates of the monthly exploitation rate, comparisons based on a binomial likelihood comparison of observed and predicted proportions resulted in somewhat higher exploitation rates, for reasons that are unclear. Unfortunately, the reasonable agreement between the agestructured and GTG model predictions is not good evidence that the monthly exploitation rate is indeed low, since the best GTG estimate of exploitation rate is highly sensitive to the assumed $\mathrm{M}_{\mathrm{o}}$; lower exploitation rates are obtained when $\mathrm{M}_{\mathrm{o}}$ is increased and higher rates when it is decreased. Absent independent estimates of $M$ from unexploited populations, the GTG model does not resolve the issue of how large the productive area $A_{\text {total }}$ really is. 
Table A2.1. Model equations

\begin{tabular}{|c|c|}
\hline \multicolumn{2}{|c|}{ Accounting equations } \\
\hline Equation 1 & $\mathrm{~N}_{\mathrm{a}+1, \mathrm{t}+1}=\mathrm{N}_{\mathrm{a}, \mathrm{t}} \mathrm{S}_{\mathrm{a}, \mathrm{t}}\left(1-\mathrm{V}_{\mathrm{a}, \mathrm{t}} \mathrm{U}_{\mathrm{t}}\right)$ \\
\hline Equation 2 & $\mathrm{~L}_{\mathrm{a}+1, \mathrm{t}+1}=\alpha_{\mathrm{t}}+\rho_{\mathrm{m}} \mathrm{L}_{\mathrm{a}, \mathrm{t}}$ \\
\hline \multicolumn{2}{|c|}{ Growth equations } \\
\hline Equation 3 & $\alpha_{\mathrm{t}}=\left(1-\rho_{\mathrm{m}}\right) \mathrm{L}_{\infty, \mathrm{t}}$ \\
\hline Equation 4 & $\mathrm{~L}_{\infty, \mathrm{t}}=\mathrm{L}_{\infty \max } /\left(1+\mathrm{k}_{\text {growth }} \Sigma \mathrm{N}_{\mathrm{a}, \mathrm{t}} \mathrm{L}_{\mathrm{a}, \mathrm{t}}{ }^{2}\right)$ \\
\hline
\end{tabular}

Oyster population numbers at age $a$ and time $t$. $\mathrm{S}_{\mathrm{a}, \mathrm{t}}$ is the monthly natural survival rate of age a oysters in month $\mathrm{t}, \mathrm{v}_{\mathrm{a}, \mathrm{t}}$ is the relative vulnerability of age a oysters to harvest, $\mathrm{U}_{t}$ is the monthly exploitation rate of fully vulnerable oysters in month $\mathrm{t}$

$\alpha_{t}$ is the Ford-Brody (incremental von

Bertalanffy) growth intercept (or size at age 1 month) parameter, and $\rho_{\mathrm{m}}$ is the Ford-Brody metabolic parameter (equal to $\mathrm{e}^{-\mathrm{K}}$ where $\mathrm{K}$ is the monthly von Bertalanffy metabolic parameter for length growth). New recruits $\mathrm{N}_{1, t}$ are added to the population each month, at body length $\alpha_{\text {,t }}$

Ford-Brody growth intercept

$\mathrm{L}_{\infty \text { max }}$ is the maximum asymptotic length that would be achieved at low population densities, $\mathrm{k}_{\text {growth }}$ is a scaling constant for effect of population density, and $\Sigma \mathrm{N}_{\mathrm{a}, \mathrm{L}} \mathrm{L}_{\mathrm{a}, \mathrm{t}}{ }^{2}$ is the sum of numbers at age times $\mathrm{L}^{2}$ as an index of relative feeding

Survival equations

Equation $5 \quad \mathrm{~S}_{\mathrm{a}, t}=\exp \left\{-\mathrm{P}_{\mathrm{y}} \mathrm{M}_{\mathrm{o}} \mathrm{L}_{\infty, \mathrm{t}} / \mathrm{L}_{\mathrm{a}, \mathrm{t}}\right\}$

Natural survival rates, assumed to vary with age and shell length, $\mathrm{M}_{\mathrm{o}}$ base natural mortality rate (around $0.1 /$ month), $\mathrm{L}_{\infty, \mathrm{t}}$ is the time and possibly density dependent maximum length (equation 4), and $P_{y}$ is an annual relative mortality rate scaler.

Vulnerability to harvest Equation $6 \quad \mathrm{v}_{\mathrm{a}, \mathrm{t}}=1 /\left(1+\exp \left\{-\left(\mathrm{L}_{\mathrm{a}, \mathrm{t}}-\mathrm{L}_{\text {legal }}\right) / \mathrm{s}_{\mathrm{a}}\right\}\right)$

Vulnerability of oysters to harvesting $\left(\mathrm{v}_{\mathrm{a}, \mathrm{t}}\right)$ represented by logistic function that represents variation in size at age around mean length $\mathrm{L}_{\mathrm{a}, \mathrm{t}}$. where $\mathrm{s}_{\mathrm{a}}=\mathrm{CV} / 1.7 \mathrm{x} \mathrm{\textrm {L } _ { \infty }}$ with $\mathrm{CV}$ around 0.13 represents variation in length at age. An $\mathrm{s}_{\mathrm{a}}$ of around 5 implies length at age near the legal size varying with a standard deviation of around $5 / 1.7$ or $2.9 \mathrm{~mm}$.

Equation $7 \quad \mathrm{U}_{\mathrm{t}}=1-\exp \left(-\mathrm{q}_{\mathrm{t}} \mathrm{E}_{\mathrm{t}}\right)$

Equation $8 \quad \mathrm{q}_{\mathrm{t}}=\mathrm{q}_{\max } /\left(1+\mathrm{k}_{\mathrm{q}} \mathrm{B}_{\mathrm{t}}\right)$ where $\mathrm{B}_{\mathrm{t}}=\sum_{\mathrm{a}} \mathrm{N}_{\mathrm{a}, \mathrm{t}} \mathrm{W}_{\mathrm{a}, \mathrm{t}} \mathrm{V}_{\mathrm{a}, \mathrm{t}}$
Monthly exploitation rates $U_{t}$ are predicted from fishing efforts $E_{t}$

$\mathrm{W}_{\mathrm{a}, \mathrm{t}}=$ weight at age, $\mathrm{q}_{\max }$ is maximum catchability (fishing mortality rate per unit effort) at low stock size, and $\mathrm{k}_{\mathrm{q}}$ is a scaling constant such that $\mathrm{q}$ is reduced to $\mathrm{q}_{\max } / 2$ when 


\section{Recruitment and shell accumulation Equation $9 \quad \mathrm{~N}_{1, \mathrm{t}}=\mathrm{LS}_{\mathrm{t}} \mathrm{AS}_{\mathrm{t}} \mathrm{SL}_{\mathrm{t}}$}

Equation $10 \quad \mathrm{LS}_{\mathrm{t}}=\mathrm{l}_{\mathrm{o}} \mathrm{R}_{\mathrm{y}} \mathrm{R}_{\mathrm{m}} \mathrm{SB}_{\mathrm{t}}$ where $\mathrm{SB}_{\mathrm{t}}=\sum_{\mathrm{a}} \mathrm{N}_{\mathrm{a}, \mathrm{t}} \mathrm{L}_{\mathrm{a}, \mathrm{t}}^{3}$

Equation $\quad \mathrm{LS}_{\mathrm{t}}=\mathrm{l}_{\mathrm{o}} \mathrm{R}_{\mathrm{y}} \mathrm{R}_{\mathrm{m}}\left(\mathrm{SB}_{\mathrm{t}} / \mathrm{SB}_{\mathrm{o}}\right)^{\beta}$

$10 \mathrm{a}$

Equation $11 \quad \mathrm{R}_{\mathrm{m}}=$ spawning component $\mathrm{x}$ predation component

$\begin{array}{ll}\text { Equation } 12 & \mathrm{AS}_{\mathrm{t}+1}=\mathrm{S}_{\text {shell }} \mathrm{AS}_{\mathrm{t}}+\mathrm{k}_{\text {shell }} \Sigma_{\mathrm{a}} \mathrm{N}_{\mathrm{a}, \mathrm{t}}(1- \\ & \left.\mathrm{S}_{\mathrm{a}, \mathrm{t}}\right) \mathrm{L}_{\mathrm{a}, \mathrm{t}}\end{array}$

Equation $13 \quad \mathrm{SL}_{\mathrm{t}}=\exp \left\{-\mathrm{k}_{\text {density }} \Sigma_{\mathrm{a}} \mathrm{N}_{\mathrm{a}, \mathrm{t}} \mathrm{L}_{\mathrm{a}, \mathrm{t}}{ }^{2}\right\}$
$B_{t}$ is half of its unfished level (i.e. $k_{q}=2 / B_{0}$ where $B_{0}$ is the predicted average biomass of the stock absent harvesting)

$\mathrm{N}_{1, \mathrm{t}}=$ monthly recruitment where $\mathrm{LS}_{\mathrm{t}}=$ annual and seasonally varying larval settlement per unit suitable shell area, $\mathrm{AS}_{\mathrm{t}}=$ suitable shell area generated from natural mortality, $\mathrm{SL}_{\mathrm{t}}=$ densitydependent survival of pre or post settlement juveniles.

$\mathrm{LS}_{\mathrm{t}}=$ Larval settlement rate where, $1_{\mathrm{o}}=$ average settlement rate, $R_{y}=$ interannual variation in larval production estimated from data, $\mathrm{R}_{\mathrm{m}}$ monthly variation in spawning and predation rate on larvae and spat, $\mathrm{SB}_{\mathrm{t}}$ spawning biomass that is proportion to body weights at age Alternative model for larval settlement assuming a power function of $\mathrm{SB}_{\mathrm{t}}$. Power parameter $\beta$ represents possible density dependence in larval or early juvenile survival rats, and/or delivery of a substantial proportion of the larvae from non-harvested spawning sources (e.g. intertidal areas where oysters never reach legal size).

Monthly variation in spawning and predation rate set by user in spreadsheet model to vary seasonally following either a unimodal spat settlement pattern peaking midsummer, bimodal recruitment pattern with high mid-summer predation loss, or unimodal spring or fall peak with high predation rates in spring or fall (patterns similar to Appendix Figure A2.1). $\mathrm{AS}_{\mathrm{t}}=$ Shell area available for recruitment following a balance rate of shell survival $S_{\text {survival }}$ (persistence of old shell) and recruitment of new shell due to natural mortality of live oysters 1$\mathrm{S}_{\mathrm{a}, \mathrm{t}} \cdot \mathrm{k}_{\text {shell }}$ is an arbitrary area scaling constant $=$ $10^{-4}$. By summing over ages of numbers, times squares of lengths, this represents age-size variation in shell area per dying oyster Density-dependent effects on larval survival and/or survival over the first month after settlement. $\mathrm{k}_{\text {density }}$ is a scaling constant for the effect per unit live oyster area present on survival rate. 


\section{Scaling parameters}

\begin{tabular}{|c|c|}
\hline Equation 14 & $1_{1,0}=1_{1, \text { fished }}=1.0$ \\
\hline & $\mathrm{l}_{\mathrm{a}, 0}=\mathrm{l}_{\mathrm{a}-1,0} \mathrm{~S}_{\mathrm{a}-1,0}, 0 \mathrm{a}>1$ \\
\hline Equation 15 & $\begin{array}{l}\mathrm{l}_{\mathrm{a}, \text { fished }}=\mathrm{l}_{\mathrm{a}-1, \text { fished }} \mathrm{S}_{\mathrm{a}-1}, 0\left(1-\mathrm{v}_{\mathrm{a}, 0} \mathrm{U}_{\mathrm{o}}\right) \\
\text { where } \mathrm{a}>1\end{array}$ \\
\hline Equation 16 & $\varphi_{\mathrm{L} 2,0}=\Sigma_{\mathrm{a}} \mathrm{l}_{\mathrm{a}, 0} \mathrm{~L}_{\mathrm{a}, 0}{ }^{2}$ \\
\hline Equation 17 & $\varphi_{\mathrm{SH}, 0}=\mathrm{k}_{\text {shell }} \Sigma_{\mathrm{a}} \mathrm{l}_{\mathrm{a}, 0}\left(1-\mathrm{S}_{\mathrm{a}, 0}\right) \mathrm{L}_{\mathrm{a}, 0}{ }^{2}$ \\
\hline Equation 18 & $\varphi_{\mathrm{B}, 0}=\sum_{\mathrm{a}} \mathrm{l}_{\mathrm{a}, 0} \mathrm{~V}_{\mathrm{a}, 0} \mathrm{~W}_{\mathrm{a}, 0}$ \\
\hline Equation 19 & $\varphi_{\mathrm{E}, 0}=\Sigma_{\mathrm{a}} \mathrm{l}_{\mathrm{a}, 0} \mathrm{vL}_{\mathrm{a}, 0}^{3}$ \\
\hline Equation 20 & $\mathrm{k}_{\text {growth }}=\left(\mathrm{L}_{\infty, \max } / \mathrm{L}_{\infty, 0^{-}}-1\right) /\left(\mathrm{R}_{\mathrm{o}}\right.$ \\
\hline Equation 21 & $\begin{array}{l}\left.\varphi_{\mathrm{L} 2,0}\right) \\
\mathrm{k}_{\mathrm{o}}=\left(\mathrm{q}_{\mathrm{max}} / \mathrm{a}_{\mathrm{O}}-1\right) /\left(\mathrm{R}_{0} \varphi_{\mathrm{B} 0}\right)\end{array}$ \\
\hline Equation 22 & $\mathrm{k}_{\text {density }}=-\ln [(1-$ \\
\hline & $\left.\left.\mathrm{S}_{\text {shell }}\right) /\left(1_{\mathrm{o}} \varphi_{\mathrm{SH}, 0}\right)\right] /\left(\mathrm{R}_{\mathrm{o}} \varphi_{\mathrm{L} 2,0}\right)$ \\
\hline
\end{tabular}

Beverton-Holt stock recruitment

Equation $23 \quad \mathrm{LS}_{\mathrm{t}}=\mathrm{kSB}_{\mathrm{t}} \mathrm{A}_{\text {set }}$

Equation $24 \quad \mathrm{~N}_{\mathrm{t}+1}=\mathrm{akSB}_{\mathrm{t}} \mathrm{A}_{\text {set }} /\left(1+\mathrm{bkSB}_{\mathrm{t}} \mathrm{A}_{\text {set }}\right)$

Equation $25 \quad \mathrm{~A}_{\mathrm{set}}=\xi \mathrm{AS}_{\mathrm{t}} /\left(1+\xi \mathrm{AS}_{\mathrm{t}}\right)$

Equation $26 \quad \mathrm{~N}_{1 \mathrm{t}}=\alpha \mathrm{R}_{\mathrm{y}} \mathrm{R}_{\mathrm{m}} \mathrm{SB}_{\mathrm{t}} \mathrm{A}$

$\mathrm{S}_{\mathrm{t}} /\left[1+\mathrm{A} \mathrm{S}_{\mathrm{t}}\left(\xi+\beta \mathrm{SB}_{\mathrm{t}}\right]\right.$

Equation $27 \quad \operatorname{Ln}\left(D_{x, y}\right)=\mu_{x}+\tau_{y}+e_{x, y}$
Unfished survivorship to age

Fished survivorship to age

Incidence function, squared lengths

Incidence function, shell production

Incidence function, vulnerable biomass

Incidence function, relative spawning biomass, equation 10

Growth scaling constants based on assuming recruitment $R_{o}$, given $\beta=0$

Catchability scaling constants based on assuming recruitment $R_{0}$, given $\beta=0$

Density scaling constants based on assuming recruitment $R_{0}$, given $\beta=0$

$\mathrm{LS}_{\mathrm{t}}=$ larval settlement at time $\mathrm{t}$ related to both relative egg production $\mathrm{SB}_{\mathrm{t}}$ and relative effective shell settlement area $\mathrm{A}_{\text {set }}$ and a constant $\mathrm{k}$

Predicted recruitment following density dependent mortality of spat following settlement

Equation describing the relationship between effective shell settlement area $\mathrm{A}_{\text {set }}$ and shell area $\mathrm{AS}_{\mathrm{t}}$. where $\xi$ is a constant that determines the shell area needed to achieve half of the maximum possible effective settlement area $(1 / \xi$ is the shell area needed to obtain $\mathrm{A}_{\text {set }}=0.5,1 / 2$ of its maximum 1.0)

Simplified Beverton-Holt stock recruitment function based on relationships in Equations 2325 after combining constants and including seasonal and annual relative recruitment multipliers $\left(R_{y}, R_{m}\right)$ where $\alpha$ represents the steepness of the stock-recruitment relationship and $\beta$ represents density-dependent mortality effects. Other terms as defined previous. Log-linear model used to estimate oyster densities for different area-year data combinations. $\mathrm{D}_{\mathrm{x}, \mathrm{y}}$ is the observed mean density for area $\mathrm{x}$ in year $\mathrm{y}, \mathrm{e}_{\mathrm{x}, \mathrm{y}}$ is combined process and sampling error for that observation, area means $\mu_{\mathrm{x}}$ were estimated as the mean density for each 
area $\mathrm{x}$ over time, while the year effects $\tau_{\mathrm{y}}$ were estimated as the mean of the deviations $D_{x, y^{-}} \mu_{x}$ in year $y$ from the overall mean densities for the areas sampled in year $y$. corrected density estimates $D^{\prime} \mathrm{x}, \mathrm{y}=\exp \left(\mu_{\mathrm{x}}+\tau_{\mathrm{y}}\right)$ were then averaged using stratum weights equal to estimated bar areas for each $\mathrm{x}$ to give weighted density estimates $\mathrm{DS}_{\mathrm{y}}$ for sublegal sized oysters and $\mathrm{DL}_{\mathrm{y}}$ for legal sized oysters for each year

\section{Estimation procedure \\ Equation $28 \operatorname{lnL}=-0.5\left[\mathrm{SS}_{\mathrm{C}} / \sigma_{\mathrm{C}}^{2}+\mathrm{SS}_{\mathrm{DACS}} / \sigma_{\text {DACS }}^{2}\right.$ $\left.+\mathrm{SS}_{\mathrm{RY}} / \sigma_{\mathrm{RY}}^{2}+\mathrm{SS}_{\mathrm{P}} / \sigma_{\mathrm{P}}^{2}\right]$}

Equation $29 \quad \mathrm{SS}_{\mathrm{DACS}}=\Sigma_{\mathrm{y}}\left[\ln \left(\mathrm{DS}_{\mathrm{y}} / \mathrm{NS}_{\mathrm{y}}\right)-\right.$ $\left.\ln \left(\mathrm{q}_{\mathrm{s}}\right)\right]^{2}+\sum_{\mathrm{y}}\left[\ln \left(\mathrm{DL}_{\mathrm{y}} / \mathrm{NL}_{\mathrm{y}}\right)-\right.$ $\left.\ln \left(\mathrm{q}_{\mathrm{s}}\right)\right]^{2}$

Equation $30 \quad \mathrm{SS}_{\mathrm{RY}}=\Sigma_{\mathrm{y}} \ln ^{2}\left(\mathrm{R}_{\mathrm{y}}\right)$

Equation $31 \quad \mathrm{SS}_{\mathrm{P}}=\sum_{\mathrm{y}} \ln ^{2}\left(\mathrm{P}_{\mathrm{y}}\right)$
Log-likelihood function for time series data assuming log-normal variation in all observed quantities, recruitment, and mortality anomalies and weighting the sums of squares deviations by assumed variances.

$\mathrm{SS}_{\text {DACS }}$ calculated by assuming observed values have averages proportional to model sublegal and legal abundances ( $\mathrm{NS}_{\mathrm{y}}$ and $\mathrm{NL}_{\mathrm{y}}$ ) obtained by adding abundances over the simulated age structure in an index month (August) each year, with constant of proportionality or survey catchability $\mathrm{q}_{\mathrm{s}}\left(\mathrm{q}_{\mathrm{s}}\right.$ is interpreted as the inverse of the number of square kilometers of oyster bar habitat at DACS densities needed to produce the model abundances). The MLE $\ln \left(\mathrm{q}_{\mathrm{s}}\right)$ is the arithmetic average over all DACS estimates of the $\ln \left(\mathrm{D}_{\mathrm{y}} / \mathrm{N}_{\mathrm{y}}\right)$ ratios.

Penalty term for recruitment anomalies Penalty term for recruitment anomalies 
Table A2.2a-d. Estimates of raw and interpolated mean oyster density (number $/ \mathrm{m}^{2}$ ) for sublegal (20-75 mm shell length) and legal (> $75 \mathrm{~mm}$ ) oysters from Florida Department of Agriculture and Consumer Services surveys on major oyster bars in Apalachicola Bay.

\begin{tabular}{|c|c|c|c|c|c|c|c|c|}
\hline \multicolumn{9}{|c|}{ (a) Raw mean oyster density (number/m²) for sublegal oysters } \\
\hline & & & & Eleven & & & & \\
\hline & Cat & Dry & East & Mile & Lighthouse & Normans & Platform & Porters \\
\hline & Point & Bar & Hole & Bar & Bar & South & Bar & Bar \\
\hline 1990 & 267.4 & & 166.0 & & 108.1 & & & \\
\hline 1991 & 220.2 & 257.4 & 158.7 & & 244.8 & & 340.9 & \\
\hline 1992 & 274.9 & 242.0 & 237.1 & & 315.6 & & & 502.4 \\
\hline 1993 & 237.5 & 151.8 & 333.4 & & 246.0 & 298.0 & & 140.8 \\
\hline 1994 & 287.7 & 305.4 & 525.2 & 132.1 & 214.9 & 332.8 & & 152.9 \\
\hline 1995 & 180.7 & 216.8 & 721.4 & 119.6 & 256.8 & & 344.9 & \\
\hline 1996 & 341.6 & 225.4 & 293.8 & & 516.9 & 430.8 & & \\
\hline 1997 & 377.7 & 122.7 & 460.8 & 106.4 & 360.4 & 329.2 & & \\
\hline 1998 & 191.7 & 105.8 & 174.1 & & 317.2 & 320.4 & & \\
\hline 1999 & 244.3 & 562.8 & 443.6 & & 246.0 & 192.1 & & \\
\hline 2000 & 379.1 & 199.6 & 332.8 & & & & & \\
\hline 2001 & 266.1 & 516.8 & 415.2 & & & & & 138.4 \\
\hline 2002 & 286.4 & 412.8 & 211.6 & 62.5 & & & & 85.2 \\
\hline 2003 & 353.7 & 283.2 & 167.2 & 164.8 & & & & 184.8 \\
\hline 2004 & 681.7 & 144.1 & 685.8 & 40.0 & & & & 657.4 \\
\hline 2005 & 180.3 & 119.7 & 184.0 & & & & & 92.9 \\
\hline 2006 & 178.0 & 500.4 & 124.4 & 462.4 & & & & 42.5 \\
\hline 2007 & 350.5 & 618.4 & 158.8 & 253.6 & & & & 168.0 \\
\hline 2008 & 148.6 & 418.6 & 198.6 & 200.2 & 170.0 & 189.1 & 256.4 & 253.3 \\
\hline 2009 & 154.1 & 261.9 & 186.1 & 169.5 & & & 229.7 & 172.7 \\
\hline 2010 & 172.1 & 242.3 & 247.2 & 139.9 & 309.2 & 224.1 & 439.7 & \\
\hline 2011 & 587.9 & 401.2 & & & & 297.6 & & \\
\hline 2012 & 48.5 & 80.0 & 34.5 & & 194.9 & 219.6 & & \\
\hline
\end{tabular}




\begin{tabular}{|c|c|c|c|c|c|c|c|c|}
\hline \multicolumn{9}{|c|}{$\begin{array}{l}\text { (b) Interpolated mean oyster density }\left(\text { number } / \mathrm{m}^{2}\right) \text { for sublegal oysters using log-linear model } \\
\text { with bar and year effects }\end{array}$} \\
\hline \multicolumn{9}{|c|}{ Eleven } \\
\hline & Cat & Dry & East & Mile & Lighthouse & Normans & & Porters \\
\hline & Point & Bar & Hole & Bar & Bar & South & Platform & Bar \\
\hline 1990 & 168.2 & 170.3 & 165.9 & 95.0 & 172.0 & 186.8 & 213.8 & 113.4 \\
\hline 1991 & 225.1 & 227.9 & 222.0 & 127.1 & 230.2 & 250.0 & 286.2 & 151.7 \\
\hline 1992 & 325.1 & 329.2 & 320.6 & 183.6 & 332.5 & 361.1 & 413.4 & 219.1 \\
\hline 1993 & 233.6 & 236.5 & 230.3 & 131.9 & 238.8 & 259.4 & 297.0 & 157.4 \\
\hline 1994 & 285.5 & 289.0 & 281.5 & 161.2 & 291.9 & 317.0 & 362.9 & 192.4 \\
\hline 1995 & 272.4 & 275.8 & 268.6 & 153.8 & 278.5 & 302.5 & 346.3 & 183.6 \\
\hline 1996 & 338.5 & 342.7 & 333.8 & 191.1 & 346.1 & 375.9 & 430.3 & 228.1 \\
\hline 1997 & 273.8 & 277.2 & 270.0 & 154.6 & 280.0 & 304.0 & 348.1 & 184.5 \\
\hline 1998 & 199.6 & 202.0 & 196.8 & 112.7 & 204.1 & 221.6 & 253.7 & 134.5 \\
\hline 1999 & 302.7 & 306.5 & 298.5 & 170.9 & 309.5 & 336.2 & 384.8 & 204.0 \\
\hline 2000 & 293.2 & 296.9 & 289.2 & 165.6 & 299.9 & 325.7 & 372.8 & 197.6 \\
\hline 2001 & 329.2 & 333.3 & 324.6 & 185.9 & 336.6 & 365.6 & 418.5 & 221.9 \\
\hline 2002 & 203.7 & 206.2 & 200.9 & 115.0 & 208.3 & 226.2 & 258.9 & 137.3 \\
\hline 2003 & 266.4 & 269.8 & 262.7 & 150.4 & 272.4 & 295.9 & 338.7 & 179.6 \\
\hline 2004 & 341.8 & 346.0 & 337.0 & 193.0 & 349.5 & 379.5 & 434.5 & 230.3 \\
\hline 2005 & 153.0 & 154.9 & 150.9 & 86.4 & 156.5 & 169.9 & 194.5 & 103.1 \\
\hline 2006 & 224.7 & 227.5 & 221.6 & 126.9 & 229.8 & 249.6 & 285.7 & 151.5 \\
\hline 2007 & 329.1 & 333.2 & 324.5 & 185.8 & 336.5 & 365.5 & 418.4 & 221.8 \\
\hline 2008 & 235.3 & 238.3 & 232.1 & 132.9 & 240.6 & 261.3 & 299.2 & 158.6 \\
\hline 2009 & 217.0 & 219.7 & 214.0 & 122.5 & 221.9 & 241.0 & 275.9 & 146.3 \\
\hline 2010 & 245.6 & 248.7 & 242.3 & 138.7 & 251.2 & 272.8 & 312.3 & 165.6 \\
\hline 2011 & 396.7 & 401.6 & 391.2 & 224.0 & 405.6 & 440.5 & 504.3 & 267.3 \\
\hline 2012 & 87.2 & 88.3 & 86.0 & 49.3 & 89.2 & 96.9 & 110.9 & 58.8 \\
\hline
\end{tabular}




\begin{tabular}{|c|c|c|c|c|c|c|c|c|}
\hline \multicolumn{9}{|c|}{ (c) Raw mean oyster density (number/m²) for legal oysters } \\
\hline \multicolumn{9}{|c|}{ Eleven } \\
\hline & Cat & Dry & East & Mile & Lighthouse & Normans & & Porters \\
\hline & Point & Bar & Hole & Bar & Bar & South & Platform & Bar \\
\hline 1990 & 23.4 & & 17.3 & & 11.9 & & & \\
\hline 1991 & 17.0 & 16.4 & 14.8 & & 40.8 & & 45.5 & \\
\hline 1992 & 20.7 & 22.4 & 18.2 & & 51.6 & & & 49.6 \\
\hline 1993 & 41.9 & 30.6 & 63.8 & & 126.8 & 134.0 & & 24.8 \\
\hline 1994 & 29.7 & 18.5 & 83.2 & 23.9 & 48.3 & 98.0 & & 44.9 \\
\hline 1995 & 46.4 & 45.6 & 184.4 & 92.8 & 74.8 & & 87.9 & \\
\hline 1996 & 31.0 & 77.8 & 203.6 & & 133.9 & 209.2 & & \\
\hline 1997 & 56.5 & 46.9 & 82.8 & 51.2 & 101.6 & 169.6 & & \\
\hline 1998 & 34.8 & 35.4 & 58.9 & & 61.6 & 100.4 & & \\
\hline 1999 & 33.7 & 24.0 & 34.4 & & 45.6 & 79.9 & & \\
\hline 2000 & 81.0 & 168.0 & 93.8 & & & & & \\
\hline 2001 & 41.1 & 59.2 & 54.4 & & & & & 62.4 \\
\hline 2002 & 24.1 & 103.6 & 32.0 & 32.7 & & & & 23.6 \\
\hline 2003 & 31.4 & 45.2 & 18.0 & 32.8 & & & & 17.2 \\
\hline 2004 & 38.6 & 40.5 & 40.2 & 47.2 & & & & 181.6 \\
\hline 2005 & 29.1 & 17.3 & 48.2 & & & & & 55.9 \\
\hline 2006 & 45.0 & 49.0 & 23.2 & 61.6 & & & & 8.3 \\
\hline 2007 & 37.0 & 68.7 & 42.8 & 36.0 & & & & 18 \\
\hline 2008 & 36.2 & 42.1 & 32.3 & 59.0 & 40.4 & 41.6 & 48.4 & 35.9 \\
\hline 2009 & 20.6 & 18.4 & 18.5 & 27.6 & & & 18.9 & 11.5 \\
\hline 2010 & 19.7 & 24.4 & 25.6 & 34.3 & 33.2 & 32.7 & 51.5 & \\
\hline 2011 & 24.3 & 29.6 & & & & 75.2 & & \\
\hline 2012 & 15.9 & 20.0 & 16.3 & & 48.3 & 40.0 & & \\
\hline
\end{tabular}




\begin{tabular}{|c|c|c|c|c|c|c|c|c|}
\hline \multicolumn{9}{|c|}{$\begin{array}{l}\text { (d) Interpolated mean oyster density }\left(\text { number } / \mathrm{m}^{2}\right) \text { for legal oysters using log-linear model } \\
\text { with bar and year effects }\end{array}$} \\
\hline \multicolumn{9}{|c|}{ Eleven } \\
\hline & Cat & Dry & East & Mile & Lighthouse & Normans & & Porters \\
\hline & Point & Bar & Hole & Bar & Bar & South & Platform & Bar \\
\hline 1990 & 13.0 & 15.4 & 16.8 & 17.4 & 22.1 & 34.4 & 18.7 & 13.0 \\
\hline 1991 & 18.3 & 21.7 & 23.5 & 24.5 & 31.1 & 48.3 & 26.3 & 18.2 \\
\hline 1992 & 24.2 & 28.7 & 31.2 & 32.4 & 41.2 & 64.0 & 34.9 & 24.1 \\
\hline 1993 & 41.4 & 49.1 & 53.3 & 55.4 & 70.4 & 109.4 & 59.6 & 41.3 \\
\hline 1994 & 30.6 & 36.4 & 39.5 & 41.0 & 52.1 & 81.0 & 44.1 & 30.5 \\
\hline 1995 & 60.2 & 71.4 & 77.5 & 80.5 & 102.4 & 159.0 & 86.7 & 60.0 \\
\hline 1996 & 72.5 & 86.0 & 93.4 & 97.0 & 123.3 & 191.6 & 104.5 & 72.3 \\
\hline 1997 & 52.5 & 62.4 & 67.7 & 70.3 & 89.4 & 138.9 & 75.7 & 52.4 \\
\hline 1998 & 36.6 & 43.4 & 47.1 & 48.9 & 62.2 & 96.6 & 52.7 & 36.5 \\
\hline 1999 & 27.1 & 32.2 & 35.0 & 36.3 & 46.2 & 71.7 & 39.1 & 27.1 \\
\hline 2000 & 94.1 & 111.7 & 121.3 & 126.0 & 160.2 & 248.8 & 135.7 & 93.9 \\
\hline 2001 & 48.2 & 57.3 & 62.2 & 64.6 & 82.1 & 127.5 & 69.5 & 48.1 \\
\hline 2002 & 31.3 & 37.2 & 40.4 & 41.9 & 53.3 & 82.8 & 45.1 & 31.2 \\
\hline 2003 & 23.4 & 27.8 & 30.2 & 31.4 & 39.9 & 61.9 & 33.8 & 23.4 \\
\hline 2004 & 48.3 & 57.4 & 62.3 & 64.7 & 82.2 & 127.7 & 69.6 & 48.2 \\
\hline 2005 & 30.7 & 36.5 & 39.6 & 41.1 & 52.3 & 81.2 & 44.3 & 30.6 \\
\hline 2006 & 26.4 & 31.3 & 34.0 & 35.3 & 44.9 & 69.8 & 38.0 & 26.3 \\
\hline 2007 & 32.2 & 38.2 & 41.5 & 43.1 & 54.8 & 85.1 & 46.4 & 32.1 \\
\hline 2008 & 29.9 & 35.5 & 38.5 & 40.0 & 50.9 & 79.0 & 43.1 & 29.8 \\
\hline 2009 & 15.6 & 18.5 & 20.1 & 20.8 & 26.5 & 41.2 & 22.4 & 15.5 \\
\hline 2010 & 21.0 & 24.9 & 27.0 & 28.1 & 35.7 & 55.4 & 30.2 & 20.9 \\
\hline 2011 & 25.8 & 30.6 & 33.2 & 34.5 & 43.9 & 68.2 & 37.2 & 25.7 \\
\hline 2012 & 17.1 & 20.3 & 22.0 & 22.9 & 29.1 & 45.2 & 24.6 & 17.0 \\
\hline
\end{tabular}


Table A2.3. Estimates of monthly exploitation rate from the age-structured model with $\mathrm{A}_{\text {total }}=5$ $\mathrm{km}^{2}$, compared to estimates from fitting the growth type group model to the average legal size distribution over 5-year periods.

\begin{tabular}{ccc}
\hline \hline Period & Age model & GTG model \\
\hline $1990-1994$ & 0.067 & 0.06 \\
$1995-1999$ & 0.02 & 0.04 \\
$2000-2004$ & 0.03 & 0.02 \\
$2005-2009$ & 0.045 & 0.06 \\
$2010-2012$ & 0.075 & 0.05 \\
\hline
\end{tabular}


Table A2.4. Apalachicola Bay oyster resource management recommendations compiled from reports from local symposia or agency assessments.

Swift 1898

- Maintain dredge fishery ban

- Extend harvest closure period to April 15 through October 15 in order to protect early spawning season

- Adhere strictly to laws regarding culling and taking of small oysters

- Improve enforcement of harvest laws and laws protecting oyster planters

- Break up and separate transplanted clusters of overcrowded oysters in order to improve growth

- Use shell as cultch for new planting locations to create productive beds

- Add cultch to depleted beds and allow to recuperate for a year or two

- Improve communication with oystermen to reduce mistrust of planting laws

Whitfield and Beaumariage 1977

- Balance protection of resources and enhancement of product marketability through technological innovation and modernization of industry

- Develop non-destructive mechanical harvesting technology

- Construct state-sponsored oyster fattening plants to allow year-round culture

- Shorten harvest season to November 1 through May 1

○ Refuse demands by oystermen for legislation allowing year-round harvest

- Adhere vigorously to harvest regulations

- Amend anti-leasing laws to encourage private management and reef development

- Continue State-directed construction of new oyster reefs and rehabilitation of existing reefs

- Inform general public on impacts of development and upstream health on coastal economy and food production

- Have resource managers work closely with resource users to implement management plans

- Initiate FDA-sponsored oyster marketing and sanitation inspection program to improve product quality

- Expand sanitary surveillance of harvesting waters

- Discourage further development, channelization, and dam construction on Apalachicola River

Andree 1983

- Environmental effects on productivity of oysters

- Correlate biological productivity of oysters with rainfall, salinity, density of predators, and other environmental parameters

- Map substrate bottom types and locations in order to improve oyster cultch planting efforts in suitable locations

- Examine sedimentation and current scour in relation to oyster spat survival in order to improve reef construction site selection

- Management and regulation of fishery resources

- Re-examine laws on undersized oyster harvest, oyster transport, and summer harvest to make law enforcement more efficient 
- Re-examine potential for submerged bottom leasing in unproductive areas that are not likely to be developed by the state's reef construction program

- Continue Florida Department of Natural Resources oyster reef construction program, but improve site selection, construction methods, and reef monitoring

- Improve communication between state agencies, researchers, and the industry through an annual forum, possibly led by the Apalachicola National River and Estuarine Sanctuary

- Develop better economic guidance for oyster dealers and oystermen

- Create functional long-range resource use plan for oysters

- Maintenance of a quality product for the market

- Increase cooperation between law enforcement, management agencies, oystermen, and oyster dealers to reduce undersized oyster harvest

- Establish water quality control procedures in oyster processing houses

- Develop simple, adequate test for Vibrio bacteria in oyster meats in order to avoid costly consumer scares

- Miscellaneous discussion

- Potential for hybridization and genetic manipulation

○ Exploration of alternative and "non-traditional" seafood products

○ Preliminary oyster "relay" projects highly successful

Arnold and Berrigan 2002

- Florida FWC should closely monitor ACF River Basin Allocation Formula agreements between Florida, Alabama, and Georgia, and should intervene to protect oyster resources in Apalachicola Bay if these freshwater allocations threaten them

- Florida FWC should carefully manage other Florida oyster resources to ensure that alternative sources are available if/when natural or anthropogenic factors result in the collapse of Apalachicola Bay oyster populations

Havens et al. 2013

- Monitoring

○ Continue monitoring oyster landings and expand fisheries independent monitoring program

- Include oysters in list of species routinely assessed by FWRI

- Management and restoration

- Improve acceptance and enforcement of rules regarding size limits, spatial restrictions, and seasonal closures

- Explore oyster leases as possible alternative to open-access fisheries (e.g. Territorial User Rights Fisheries)

- Evaluate efficacy and cost effectiveness of different shell planting materials and strategies, and expand cultching efforts

$\circ$ Involve state agencies and university experts in long-term fishery management process

- Research

- Evaluate "relay" practices and potential for recruitment overfishing

- Identify optimal approach for monitoring long-term oyster characteristics

$\circ$ Quantify interactions of oyster population dynamics, product quality, and the 
fishery with river flow, nutrients, salinity, harvesting intensity, and restoration methods

- Assess oystermen harvesting practices and adaptation to changes in oyster abundance

- Use ECOSPACE model to identify effects of varying flow regimes and flow alternatives on oyster population dynamics and harvest potential

- Outreach and education

- Develop community-based outreach and education program

- Involve oyster harvesters and processors in research and restoration projects

- Miscellaneous discussion

○ Exploration of alternative and "non-traditional" seafood products 
(a)

Relative recruitment (mean=1)

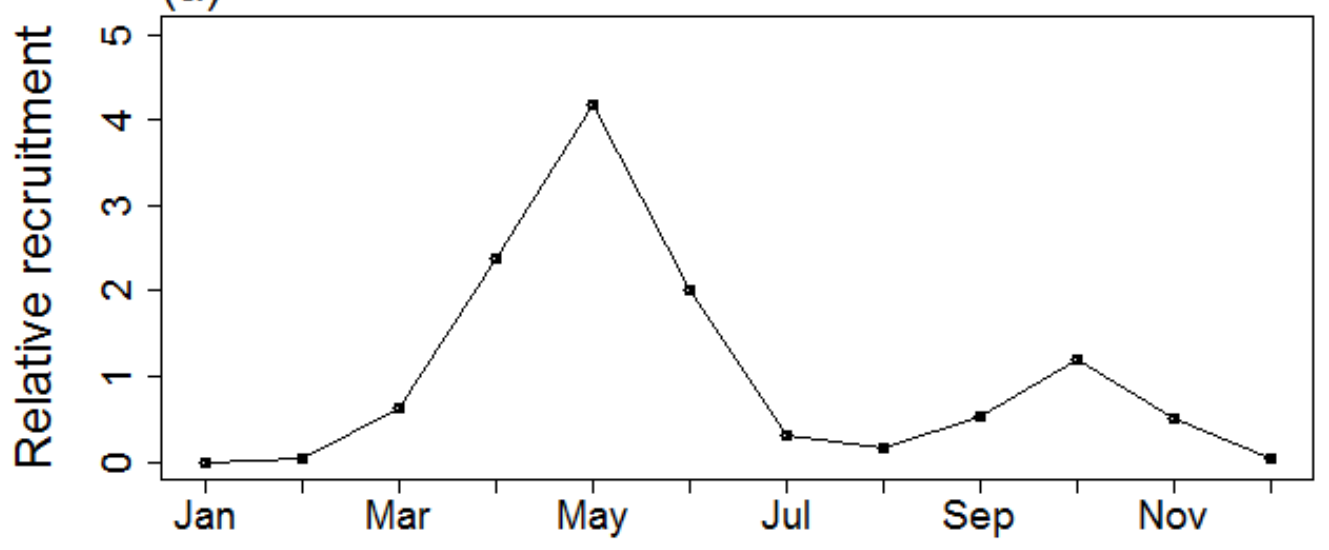

(b) Relative growth (mean=1)

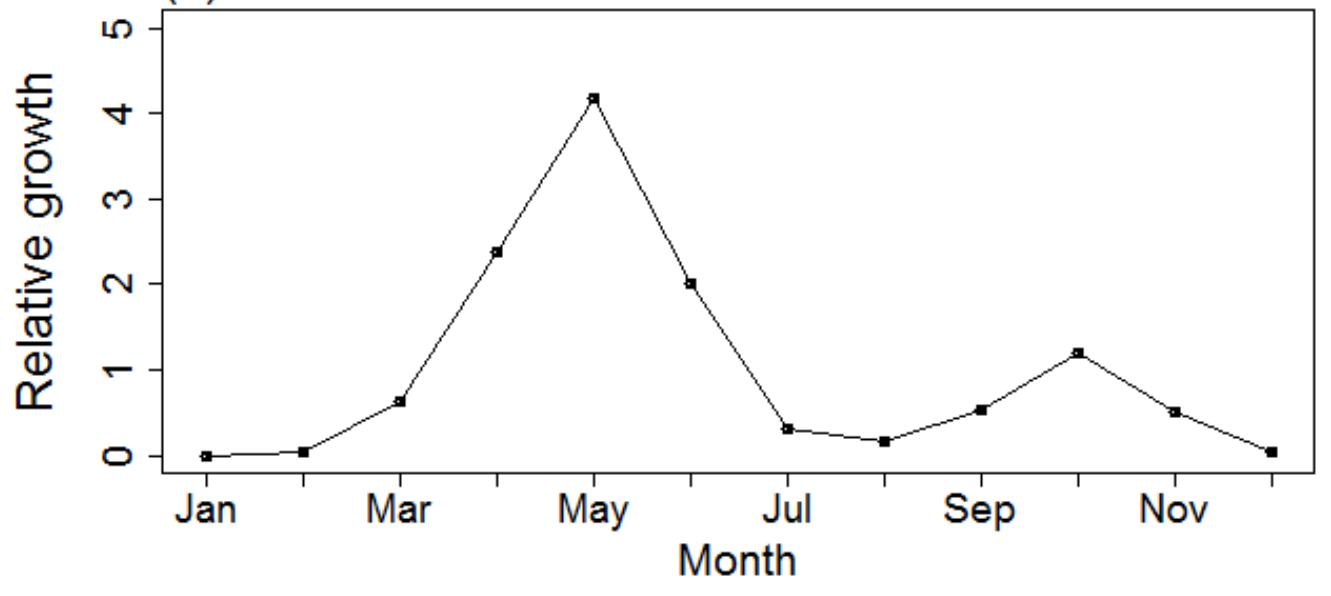

Figure A2.1. Monthly relative recruitment (a) and growth patterns (b) assumed for oysters in Apalachicola Bay, Florida based on empirical assessment of growth patterns and literature review. 


\section{Apparent catchability vs. Oyster density}

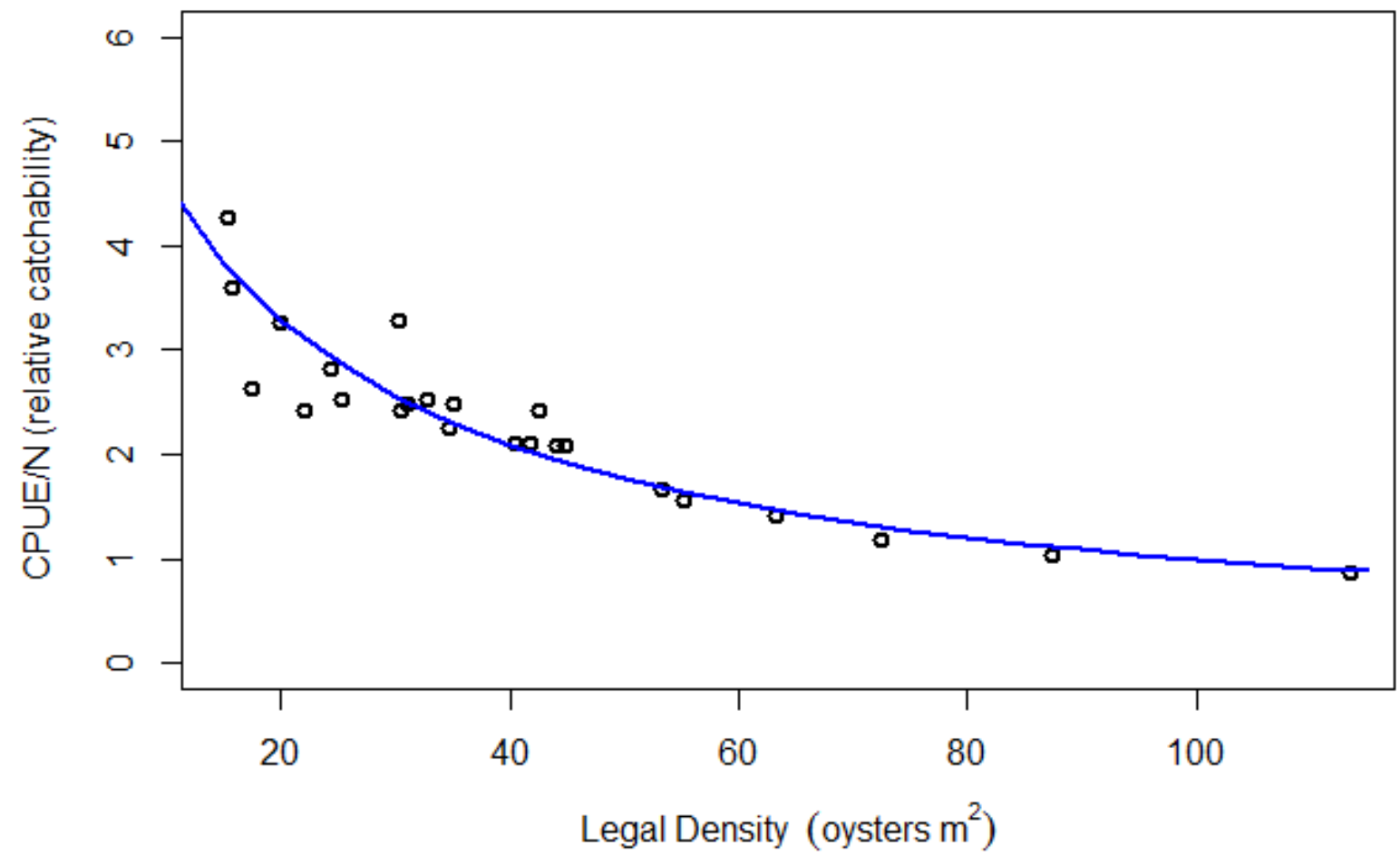

Figure A2.2. Density dependence in relative catchability $q$ as evidenced by variation in mean annual catch per unit effort (CPUE), measured as trips per year divided by mean legal oyster density from DACS surveys. Assuming constant area swept per tong lift, this relationship implies that number of tong lifts per trip increases by a factor of about 4 when densities drop from around 100 legal oysters $/ \mathrm{m}^{2}$ to the observed low of near $10 / \mathrm{m}^{2}$. 

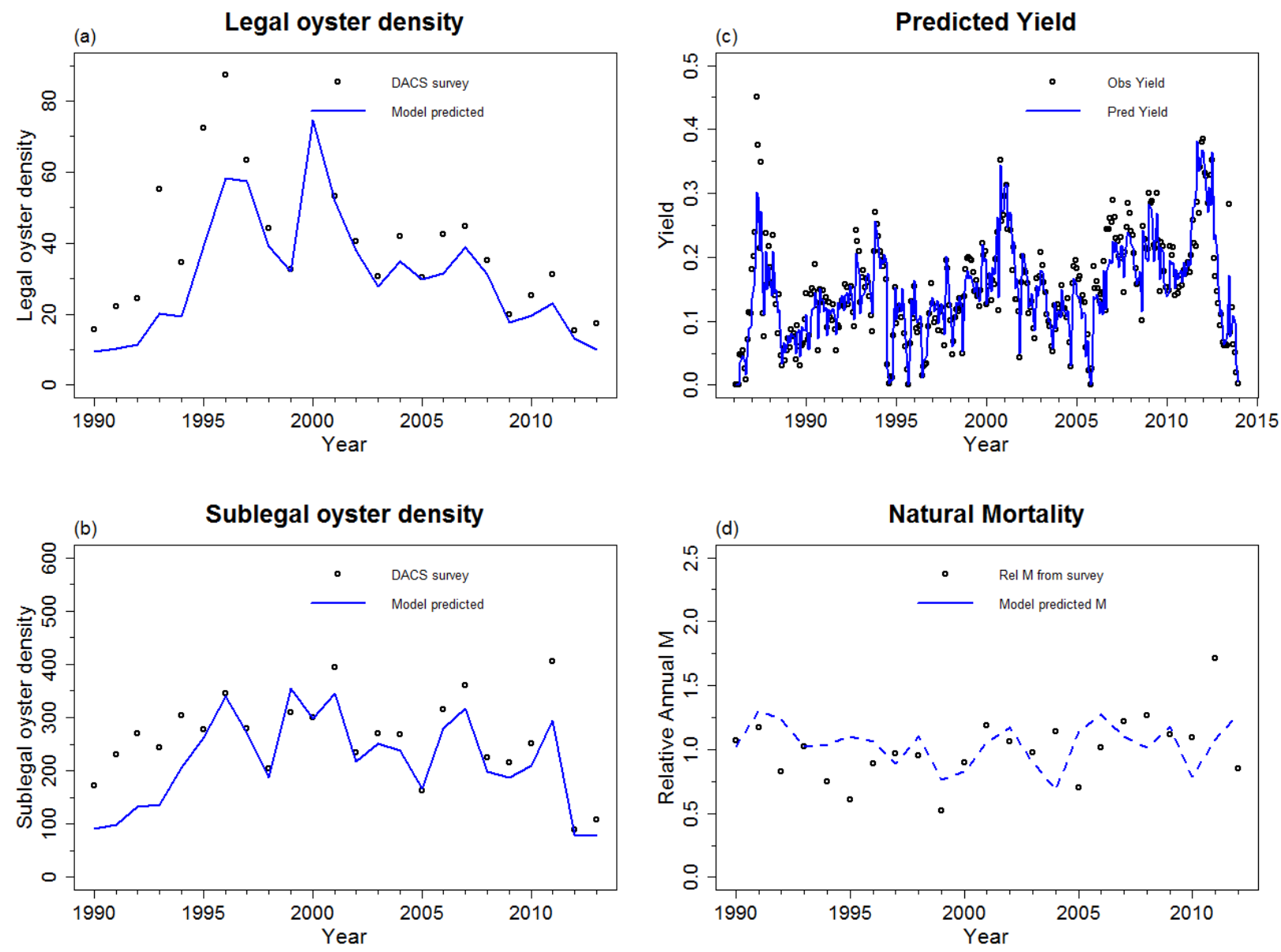

Figure A2.3. Observed (black circles) and model predicted (blue line) trends in legal (> 76.2 $\mathrm{mm}$, panel (a) and sub-legal (b) oyster abundance, predicted oyster fishery yield (c), and estimated natural mortality rate (d) in Apalachicola Bay from 1990-2013. Model prediction results are from applying the parameter estimation procedure assuming balanced impacts of variation in natural mortality rate and recruitment rate. Observed data are from Florida Department of Agriculture and Consumer Sciences (DACS) fisheries independent surveys and predictions are from age-structured model described in this paper for comparison. Note large reduction in recruitment rates for 2012-3 implied by forcing the model to fit the DACS density estimates. 


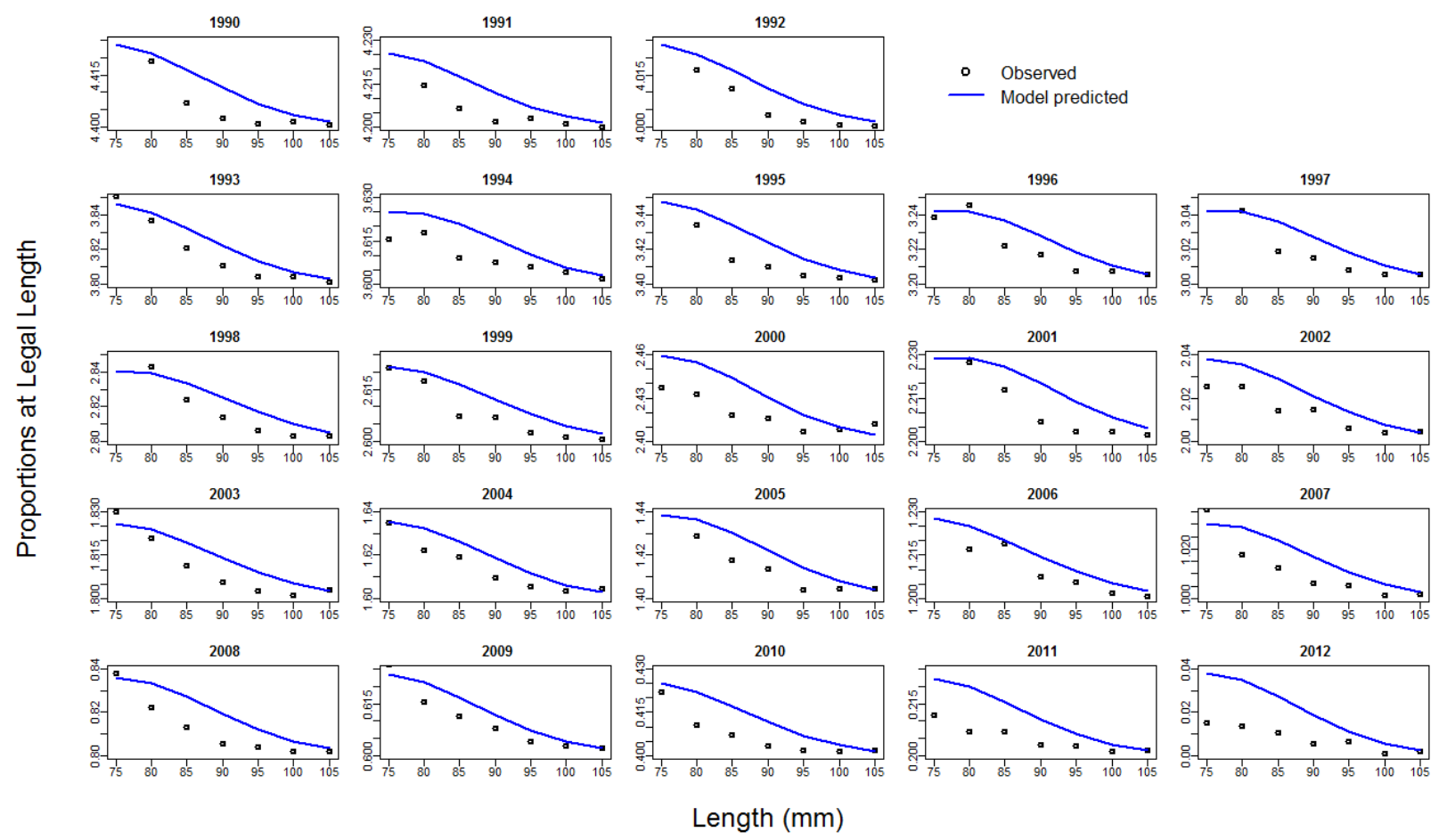

Figure A2.4. Comparison of model-predicted length proportions of legal sized oysters in Apalachicola Bay, Florida during fall (blue line) and observed length proportions of legal size oysters (black circles) in fisheries independent surveys conducted in fall by the Florida Department of Agriculture and Consumer Services. 


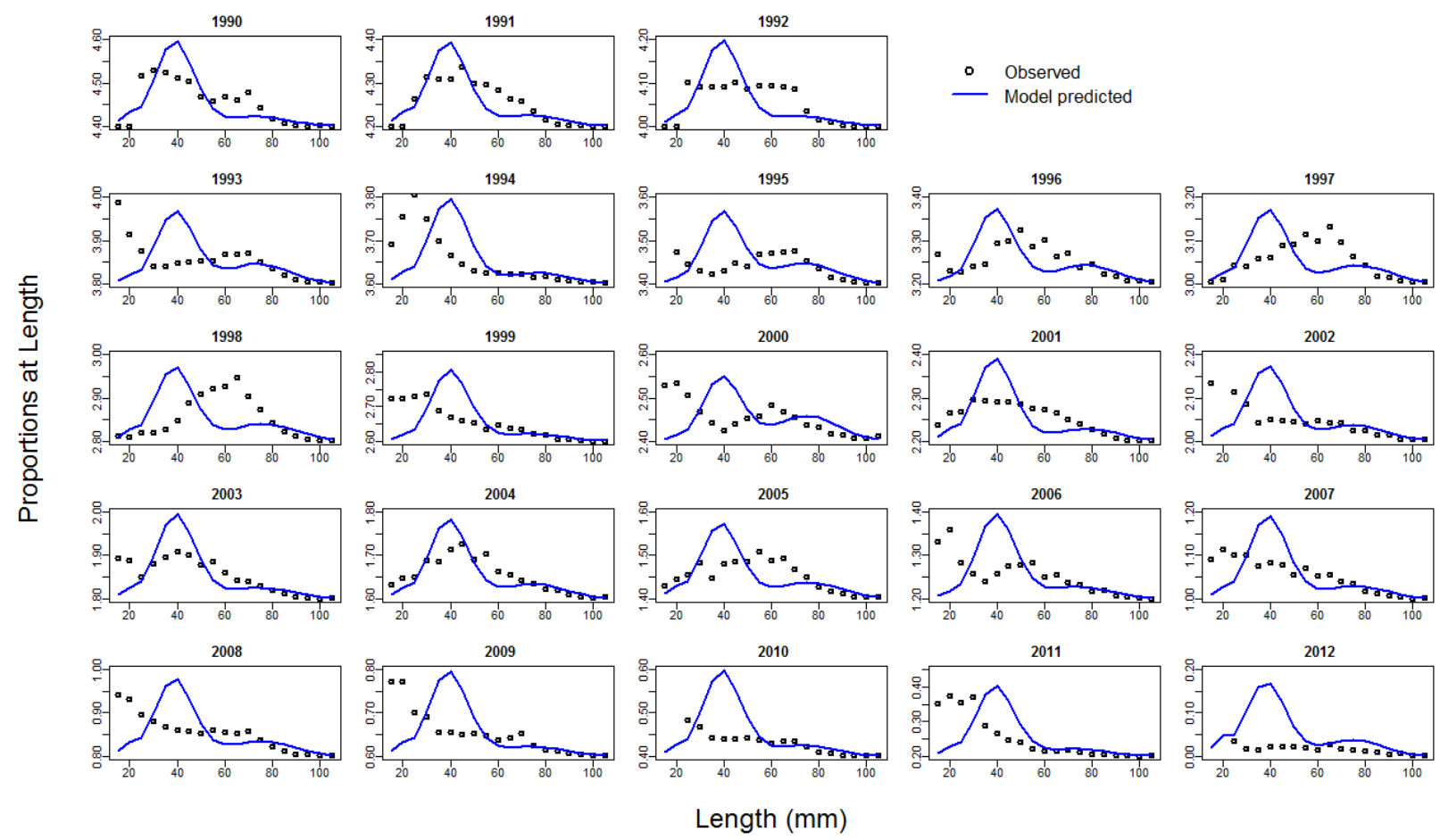

Figure A2.5. Comparison of model predicted length proportions of oysters $15-105 \mathrm{~mm}$ in size from Apalachicola Bay, Florida during fall (blue line) and observed length proportions of legal size oysters (black circles) from fisheries independent surveys conducted in fall by the Florida Department of Agriculture and Consumer Services. 
References

Andree, S., editor. 1983. Apalachicola oyster industry: Conference proceedings. University of Florida Sea Grant Program, Report No. 57, Gainesville, Florida, USA.

Arnold, W. S., and M. E. Berrigan. 2002. A summary of the oyster (Crassostrea virginica) fishery in Florida. A Report to the Division of Marine Fisheries, Florida Fish and Wildlife Conservation Commission, St. Petersburg, Florida, USA.

Havens, K., M. Allen, E. Camp, T. Irani, A. Lindsey, J. G. Morris, A. Kane, D. Kimbro, S. Otwell, B. Pine, C. Walters. 2013. Apalachicola Bay Oyster Situation, University of Florida Sea Grant Program, Report No. TP-200, Gainesville, Florida, USA.

Hayes, P. F., and R. W. Menzel. 1981. The reproductive cycle of early setting Crassostrea virginica (Gmelin) in the northern Gulf of Mexico, and its implications for population recruitment. The Biological Bulletin 160:80-88.

Hilborn, R., and C. J. Walters. 1992 Quantitative Fisheries Stock Assessment: Choice, Dynamics and Uncertainty. Chapman and Hall, London, England.

Ingle, R. M., and C. E. Dawson, Jr. 1952. Growth of the American oyster, Crassostrea virginica (Gmelin) in Florida waters. Bulletin of Marine Science 2:393-404.

Swift, F. 1898. The oyster-grounds of the west Florida coast: Their extent, conditions, and peculiarities. Pages 185-187 in Proceedings and Papers of the National Fishery Congress, Tampa, Florida, January 19-24, 1898. US Commission of Fish and Fisheries. Washington, D. C., USA.

Twichell, D. C., B. D. Andrews, H. L. Edmiston, and W. R. Stevenson. 2006. Geophysical mapping of oyster habitats in a shallow estuary: Apalachicola Bay, Florida. US Geological Survey, Open-File Report 2006-1381, Woods Hole, Massachusetts, USA.

Twichell, D., L. Edmiston, B. Andrews, W. Stevenson, J. Donoghue, R. Poore, and L. Osterman. 2010. Geologic controls on the recent evolution of oyster reefs in Apalachicola Bay and St.

George Sound, Florida. Estuarine, Coastal and Shelf Science 88:385-394.

Walters, C.J., and D. Ludwig. 1994. Calculation of Bayes posterior probability distributions for key population parameters. Canadian Journal of Fisheries and Aquatic Sciences 51:713-722.

\section{http://dx.doi.org/10.1139\%2Ff94-071}

Walters, C. J., and S. J. Martell. 2004. Fisheries ecology and management. Princeton University Press, Princeton, New Jersey, USA.

Walters, C. J., and J. R. Post. 1993. Density-dependent growth and competitive asymmetries in size-structured fish populations: a theoretical model and recommendations for field experiments. Transactions of the American Fisheries Society 122:34-45. 
http://dx.doi.org/10.1577\%2F1548-

8659\%281993\%29122\%3C0034\%3ADDGACA\%3E2.3.CO\%3B2

Whitfield, W.K. Jr, and D.S. Beaumariage. 1977. Shellfish management in Apalachicola Bay: past-present-future. Pages 130-140 in R. J. Livingston and E. A. Joyce Jr, editors. Proceedings of the Conference on the Apalachicola Drainage System. Florida Department of Natural Resources, Florida Marine Resource Publication No. 26, Tallahassee, Florida, USA. 